\title{
Embryonic Politics: Attitudes about Abortion, Stem Cell Research, and IVF* $^{*}$
}

\section{Heather Silber Mohamed Clark University}

\begin{abstract}
Efforts by anti-abortion advocates to introduce "personhood" initiatives, which state that human life begins at fertilization, have prompted concern among infertility specialists that these initiatives would hinder access to in vitro fertilization (IVF). Yet, our understanding of public opinion about IVF is limited. It remains unclear whether attitudes about this technology are consistent with opinions about other issues related to human embryos, particularly abortion and embryonic stem cell (ESC) research. Using data from a nationally representative survey, I fill this gap by exploring the role that religion plays in shaping attitudes about a range of embryonic politics issues. I find that religiosity, income, and ideology strongly influence whether individuals view these issues in moral terms. Respondents who are most devout and Evangelical Protestants are most likely to consistently oppose all three embryonic politics issues. Yet, the relationship between religion and attitudes about the morality of each procedure is also influenced by the procedure's outcome, with religion most influential with respect to abortion attitudes and least influential in the case of IVF. Additionally, women are less likely than men to describe IVF as morally wrong, while, in comparison to non-Hispanic whites, Latino respondents are more likely to do so.
\end{abstract}

Replication Data. Replication data is publicly available on the website of the Pew Research Center Religion and Public Life Project.

Address correspondence and reprint requests to: Heather Silber Mohamed, Clark University, Worcester, MA, USA. E-mail: hsilbermohamed@clarku.edu

*For their assistance with this paper, the author is grateful to the anonymous reviewers as well as Shanna Pearson-Merkowitz, Maria Angelica Bautista, and the Gender and Political Psychology Writing Group, particularly Ray Block and Heather Ondercin for their feedback, and Jennie SweetCushman for organizing a writing retreat during which much theoretical development for this paper took place. The author is also thankful for the excellent research assistance provided by Sadia Priyanka and Nina Thacker, and for support from Clark University. An early draft of this paper was presented at the 2017 Midwest Political Science Association Annual Meeting, and Diana Elena Burlacu provided very constructive discussant feedback. 


\section{INTRODUCTION}

In recent years, efforts to restrict access to abortion have extended into "personhood" legislation, which would define the start of human life as the moment an embryo is fertilized. Such proposals have been advanced in dozens of states across the country as well as at the national level. For instance, in January 2017, U.S. House Representative Jody Hice (R-GA) re-introduced federal legislation (H.R. 586), which provides that "human life shall be deemed to begin with fertilization." Personhood proposals have evoked loud protests from advocates and practitioners in the infertility community, who express concerns that if passed, the legislation would criminalize the disposal of embryos during the process of treatments such as in vitro fertilization (IVF).

Abortion is thought to be a classic example of morality politics, which emphasizes the importance of values, identity, and beliefs in shaping policy attitudes (Haider-Markel and Meier 1996; Doan 2014, HeidtForsythe Forthcoming; Tatalovich, Smith and Bobic 1994; Hunter, Davison and Davis 1995; Schroedel 2000; Mooney 2001). Embryonic stem cell (ESC) research, in which scientists conduct medical research on donated human embryos, is also frequently placed in this category. A significant body of scholarship examines attitudes about both of these issues, emphasizing the importance of both religiosity, or strength of religious feelings, and religious denomination in shaping public opinion (Luker 1984; Wilcox and Norrander 2002; Jelen and Wilcox 2003; Ho, Brossard and Scheufele 2008; Liu and Priest 2009; Fortin and Abele 2016). In contrast, our understanding of the extent to which religion influences attitudes about IVF is more limited.

IVF is the most common example of an assistive reproductive technology (ART), in which eggs or embryos are handled outside the body, typically in a laboratory setting, in order to achieve pregnancy (Sunderam et al. 2015). ARTs are now widely used in the United States; in 2014, an estimated 208,604 ART cycles accounted for 70,589 pregnancies (Centers for Disease Control). Yet, little is known about public opinion toward these procedures, and existing research suggests a confounding dynamic between attitudes about infertility treatments and other policies involving human embryos.

What role do religiosity and religious denomination play in shaping attitudes about a range of procedures involving "embryonic politics," or political debates surrounding medical procedures that involve human embryos? Abortion, ESC research, and ARTs may all fall under the 
broad category of embryonic politics, yet central differences emerge surrounding the policies and stakeholders of each of these procedures. While the debate over abortion pits the rights of an embryo against the rights of a pregnant woman, the debate over ESC research positions the rights of an embryo against potential remedies to a wide range of maladies (Dolgin, Fisher and Shapiro 2008). Moreover, while ESC research represents the promise of curing existing diseases, IVF represents the promise of creating new life, with the goal of family formation. Thus, questions about IVF push the debate over the status of embryos into more complicated terrain.

In this paper, I test whether individuals hold consistent attitudes about a range of policies that involve the destruction of human embryos. Using 2013 data from a nationally representative survey by the Pew Research Center, I examine which individuals are most likely to describe abortion, ESC research, and IVF as morally wrong, while also exploring characteristics associated with consistency across policy areas. I find that respondents who are most religious and those who identify as Evangelical Protestant are most likely to consistently oppose all three procedures on moral grounds. Additionally, the relationships between attitudes about embryonic politics and both religiosity and religious denomination are significantly influenced by the outcome of the procedure, with the relationship strongest with respect to abortion and weakest for IVF.

\section{MORALITY AND EMBRYONIC POLITICS}

The concept of morality politics first emerged in the 1980s to describe the policies that focus on the regulation of social norms (Mooney and Lee 1995; Lowi 1998; Tatalovich and Daynes 2011; Heidt-Forsythe 2013). In contrast to the classic redistributive policies, which seek to redistribute goods or services, morality politics seek to "redistribute" values (Meier 1994; Mooney and Lee 1995; Haider-Markel and Meier 1996; Schroedel 2000). When compared with economic policy, debates over morality policy tend to be more ideological, more polarizing, and less open to compromise, often reflecting policy disputes that are part of the "culture wars" (Mooney and Lee 1995; Lowi 1998). While abortion and ESC research are frequently cited as examples of morality politics, the extent to which IVF fits under the morality politics category remains unclear. Indeed, not all issues related to reproductive rights can be viewed through a culture wars lens; for instance, as Deckman and 
McTague (2015) demonstrate, in contrast to abortion, the debate over a birth control mandate is more aptly understood in the context of attitudes about the role of government and opportunities for women.

Although there is substantial overlap across these embryonic politics issues, they also have very different political histories. In contrast to the centuries-old debate over abortion, ESC research and IVF are both relatively new technologies. The first child was born through IVF in 1978, and the first human ESC research was conducted in 1998 (Bancoff 2011). ${ }^{1}$ As discussed below, the distinct histories and framing that characterize these political debates have the potential to influence attitudes about each policy, both collectively and individually.

In a classic work on popular attitudes, Converse (1964) argues that the mass public is not "constrained" by overarching belief systems. In other words, people do not hold consistent opinions, particularly surrounding specific issue positions. While opinions about the status of embryos influence attitudes in the abortion debate, the extent to which they shape attitudes about other procedures that involve the disposal of embryos remains unclear. Below, I extend this scholarship to explore whether IVF is consistent with the morality politics framework typically associated with other policies involving human embryos. Because attitudes about the status of embryos are frequently shaped by religious beliefs, I focus in particular on religiosity and religious denomination.

\section{Abortion}

States first began to outlaw abortion around 1820 , and by 1880 , most states across the United States had banned the procedure, with some exceptions if the life of the mother was at risk (Petchesky 1984; Reagan 1997; Haugeberg 2017). During this time period, opposition to abortion emphasized traditional gender norms, and also had a racialized component, with some anti-abortion advocates concerned about falling Protestant birth rates amid a rising immigrant population (Reagan 1997).

In 1973, the Supreme Court's decision in the Roe v. Wade case legalized the procedure, transforming the politics of the abortion debate. After Roe, the anti-abortion movement switched its focus away from preserving the traditional family unit toward an emphasis on the status of embryos and fetuses (Dolgin, Fisher and Shapiro 2008). The contemporary moral debate over abortion, including discussions about "fetal personhood" and whether an embryo deserves the same protections as 
other human life, is relatively recent; while today's opponents often portray abortion as a crime, even invoking the term "infanticide," this rhetoric did not characterize earlier abortion debates (Tribe 1992; Ferree 2002).

Contemporary pro-life advocates are more likely to view embryos at the point of conception as human life, while pro-choice advocates typically take a gradualist approach to personhood, viewing the embryo as potential human life that develops into personhood at some point after conception (Luker 1984). These underlying attitudes influence opinions about whether it is morally appropriate to destroy or discard human embryos. Individuals who view embryos as morally equivalent to human beings argue that these embryos should have the same rights as people, meaning that it is immoral to destroy or dispose of them. On the other extreme, some pro-choice advocates see embryos as having no moral status whatsoever and believe they should not warrant any special protection (Hudson, Scott and Faden 2005). Consistent with this approach, some feminists argue that the idea of fetal personhood is objectionable "because what makes human life distinct is its capacity for consciousness and sociability," whereas fetal personhood "demean(s) human life and the moral value of consciousness" (Petchesky 1984, 341). Finally, others take a middle view, that human embryos deserve some moral treatment, but to a lesser extent than a child outside of the womb. This perspective suggests that under certain conditions, destroying embryos may be morally acceptable.

In contrast to IVF, which is commonly seen as a procedure reserved for upper class white women (Bell 2009), abortion rates are higher among unmarried, low-income, and African-American women (Finer and Henshaw 2006). Thus, in addition to being a morality politics issue, there are also distinct intersectional implications to the abortion debate compared with IVF and ESC research.

Generally speaking, existing scholarship suggests that religious views and practice are more influential than demographics in shaping abortion attitudes. A strong and persistent relationship exists between religiosity and abortion attitudes, with those who are more devout more likely to be pro-life (Luker 1984; Wilcox and Norrander 2002; Jelen and Wilcox 2003; Jelen 2014; Lizotte 2015). Religious denomination also plays a role in shaping public opinion on this issue, as do partisanship and ideology (Jelen and Wilcox 2003; Cook, Jelen and Wilcox 1992). Most research suggests that there is no relationship between gender and abortion attitudes, and some scholars find that men may even hold more liberal views (Cook, Jelen and Wilcox 1992; Huddy, Cassese and Lizotte 
2008; Jelen and Wilcox 2003; Wilcox and Norrander 2002; Jelen 2014), with women more likely to view abortion as morally wrong (Scott 1989). However, Scott and Schuman (1988) find that among pro-choice supporters specifically, the issue of abortion rights is of greater importance to women than to men, while Lizotte (2015) argues that religiosity accounts for the unexpected null relationship between gender and abortion attitudes. Although African Americans used to be more likely to oppose abortion, this association appears to have diminished over time, and possibly even reversed (Strickler and Danigelis 2002; Jelen and Wilcox 2003; Carter, Carter and Dodge 2009). I seek to better understand the extent to which these relationships hold across a range of embryonic politics issues. Given the strong relationship between religion and morality, I am especially interested in the extent to which religion similarly influences attitudes about other embryonic politics issues.

\section{ESC Research}

Stem cell research involves the use of certain types of cells to research and develop cures for various diseases. Because stem cells have regenerative capabilities, and the unique ability to transform into any of the types of cells in the human body ("pluripotent"), these cells provide possibilities for cell-based therapies and treatments for a wide range of diseases, including spinal cord injuries, diabetes, cardiovascular disease, and beyond (NIH Stem Cell Information Home Page 2016).

Medical research is conducted on two categories of stem cells: nonESCs, which are found in various organs and tissues in the human body; and ESCs, which are derived from embryos fertilized in vitro that are donated through an informed consent process (NIH Stem Cell Information Home Page 2016). Given the focus of this paper, I look specifically at attitudes toward ESC research. ${ }^{2}$

Both the news media and political elites portray ESC research as a moral issue (Nisbet, Brossard and Kroepsch 2003; Ho, Brossard and Scheufele 2008; Clifford and Jerit 2013) because, like abortion, this technique raises questions about the status of embryos. ${ }^{3}$ ESC research has also been described as a "wedge" issue, with the potential to pull voters from one party to another (Hillygus and Shields 2014). Among abortion opponents who believe that embryos are the moral equivalent of human beings from conception, we would expect to see similar opposition to ESC research. However, while the goal of abortion is arguably the destruction 
of life, the goal of ESC research is to create new cures that will lessen human suffering (Meilander 2001). This distinction shifts the ethical debate to questions about whether it is appropriate to sacrifice embryos for the greater good of the community (McGee and Caplan 1999).

Disputes over ESC research reflect partisan disagreements over abortion, as well as broader debates about the role of government, religion, and science in society (Thompson 2013). Much of the policy debate over ESC research has focused primarily on government funding, including whether the government should support a procedure to which some citizens are morally opposed. For instance, in 2001, Republican President George W. Bush limited federal funding for ESC research to existing stem cell lines, banning research on new cell lines or newly derived cells. Democratic President Barack Obama overturned this restriction in 2009.

As with the abortion debate, the Catholic Church and some other Christian groups actively oppose ESC research, arguing that destroying an embryo would be "essentially equivalent to murder" (Nisbet, Brossard and Kroepsch 2003, 135). At the same time, other religious groups have declined to take a position on the issue, and some Jewish and more liberal Christian groups have advocated in support of ESC research (Vestal 2008).

With respect to public opinion, while some similarities are evident in attitudes about these procedures, not all abortion opponents consistently oppose ESC research (Dolgin, Fisher and Shapiro 2008). Indeed, even at the elite level, some pro-life politicians have publicly supported ESC research. For instance, in 2005, then-Senate Majority Leader Bill Frist (R-TN) publicly broke with President Bush, citing the "truly magnificent, truly remarkable properties" of stem cells (Connolly 2005). Similarly, I anticipate that overall, a smaller share of the population will view ESC research, as compared with abortion, as morally objectionable and a greater share will view it as not a moral issue. I also expect that, compared with abortion attitudes, there will be a weaker relationship between attitudes about ESC research and religiosity or religious denomination.

\section{In Vitro Fertilization}

Individuals in the United States increasingly use assisted reproductive technologies (ARTs) to conceive. In 1996, the first year in which the Centers for Disease Control began to collect comprehensive data, 64,036 ART cycles were performed, and 20,597 babies were born from these procedures (Sunderam et al. 2015). These figures have increased 
more than threefold in the last 20 years. Yet, even as the use of ARTs has grown substantially, our understanding of attitudes toward these procedures remains limited.

Similar to other policies involving human embryos, questions about the morality of IVF likewise focus on when human life begins, and whether the destruction of an embryo is equivalent to the destruction of human life. In a typical IVF cycle, more embryos are produced than are actually used, leading to a debate over what to do with surplus fertilized embryos. Options include freezing them indefinitely, donating them for ESC research, making them available for adoption, or disposal (Nachtigall et al. 2005). Other questions relate to the number of embryos transferred during IVF: while the American Society of Reproductive Medicine (ASRM) has clear guidelines, no federal laws exist to prevent large numbers of embryos from being implanted. ${ }^{4}$ The transfer of multiple embryos can result in multifetal pregnancies, leading to debates over techniques by which one or more fetuses are "reduced" or aborted. ${ }^{5}$

Class inequality significantly limits access to IVF, which is not covered by most private insurance plans or Medicaid. As of March 2017, the ASRM (ND) listed the cost of a single cycle of IVF as $\$ 12,400$, while another study placed the median cost at $\$ 19,200$ (Wu et al. 2014). Despite the fact that racial and ethnic minorities are disproportionately affected by infertility, other structural and cultural factors also result in inequalities of access (Spar 2006; Inhorn and Birenbaum-Carmeli 2008; Culley, Hudson and van Rooj 2013). Another indicator of the complex politics behind ARTs is the mixed reaction of feminist groups (Donchin 1986; Franklin 1995). While most feminist organizations have been strong advocates for reproductive rights, they have largely avoided embracing the cause of expanding access to IVF (Donchin 1996; Harwood 2007; Heidt-Forsythe 2013; Mottier 2013).

When IVF was still in its early stages, the National Institute of Health created an Ethics Advisory Board (EAB) to evaluate this procedure. The Board's 1979 report concluded that the "human embryo is entitled to profound respect; but this respect does not necessarily encompass the full legal and moral rights attributed to persons" (quoted in Bonnicksen 1989, 79). Following an outpouring of public feedback against these conclusions, IVF became "a pariah attached to the politically dangerous issue of abortion" (Bonnicksen 1989, 81). Since this report, the federal government has largely avoided involvement in debates surrounding ARTs, in contrast to other policies related to embryos (Bonnicksen 1989, Jasanoff 2011, Stapleton and Skinner 2015). Given the exponential growth of 
IVF since 1979, it remains unclear whether the early link identified between IVF and abortion persists, and to my knowledge, no empirical research has examined this question.

In general, questions of embryo disposal and destruction in IVF have not been subject to the same fierce political debates surrounding abortion and, to a lesser extent, ESC research. Rather, ARTs occupy an intermediate policy space, "stretch(ing) the boundaries of current conceptualizations of morality policy," while also incorporating business and scientific interests (Heidt-Forsythe 2013, 20).

Scholarship on public opinion toward abortion is expansive, and a substantial body of research also exists on attitudes regarding stem cell research. Far less research examines public opinion about IVF. Adashi et al. (2000) report on the first large-scale international survey on infertility, but their primary emphasis is cross-national. Other research on ART attitudes in the United States is based on limited samples, but points to a relationship between partisanship/ideology and IVF, with Democrats more likely to support the procedure and conservatives more likely to oppose (Shreffler, Johnson and Scheublec 2010; Sigillo, Miller and Weiser 2012; Fortin and Abele 2016). Fortin and Abele (2016) find that religiosity, measured by attendance at religious services, is associated with more negative attitudes about IVF, but that Catholic women are actually more supportive compared with non-Catholics, a counterintuitive finding given the Church's strong opposition to abortion.

Existing research on the range of embryonic politics issues yields four hypotheses.

H1: Given the hybrid position of ARTs, their distinct history, and rapid growth, I anticipate that compared with abortion and ESC research, far fewer people will describe IVF as morally wrong.

At the same time, I expect that some respondents will hold constrained, or consistent, attitudes about embryonic politics. In particular, religion strongly influences attitudes about the status of embryos, particularly among conservative Christians (Luker 1984; Wilcox and Norrander 2002; Jelen and Wilcox 2003; Ho, Brossard and Scheufele 2008; Liu and Priest 2009; Fortin and Abele 2016). There is also a relationship between religion and "constrained political attitudes" (Pearson-Merkowitz and Gimpel 2009). This research yields two additional hypotheses.

H2: There will be a positive relationship between religiosity, or strength of religious feelings, and embryonic politics attitudes. More devout respondents will be more likely to describe all procedures as morally 
wrong and will be more likely to oppose abortion, followed by ESC research and then IVF.

Both Catholics and Evangelical Protestants strongly emphasize that life begins at the moment of conception (Ellison, Echevarría and Smith 2005). At the elite level, office holders who are Evangelical Christian and those representing Evangelical districts are most conservative on culture wars issues, with Catholics and mainline Protestants in the middle, and Jews most liberal (Oldmixon and Calfano 2007; McTague and PearsonMerkowitz 2013). However, prior research suggests that Catholics find abortion more morally objectionable than both mainline and Evangelical Protestants (Scott 1989) and are more likely to strongly oppose the procedure (Scott and Schuman 1988). Moreover, to date, only the Catholic Church has spoken out specifically against IVF (Fortin and Abele 2016). A recent study on Senators' voting patterns finds that Evangelical Protestant and Jewish office holders are the most constrained in their views on culture wars issues, including abortion, with Evangelical Protestants in opposition and Jews most supportive (McTague and Pearson-Merkowitz 2015). Indeed, Jewish Americans have traditionally been more pro-choice (Cook, Jelen and Wilcox 1992; Jelen and Wilcox 2003), and Jewish organizations have advocated in support of ESC research (Holland, Lebacqz and Zoloth 2001), while internationally, Israel had the highest number of fertility clinics per capita and the highest rate of IVF treatments (Kahn 2000).

H3: Compared with mainline Protestants, Evangelical Protestants and Catholics will be more likely to describe all three procedures as morally wrong, while Jewish respondents will be more likely to describe them as morally acceptable.

H4: As with religiosity, the relationship between both religious denomination and attitudes about embryonic politics issues will be strongest for abortion and weakest for IVF, with ESC research in the middle.

\section{DATA AND METHODS}

I evaluate these hypotheses using data from the Pew Research Center Religion and Public Life Project's 2013 Survey on Aging and Longevity (Pew Research Center 2013). ${ }^{6}$ This survey was conducted using a national landline and cell phone sample of 4,006 adults across the United States between March 21 and April 8, 2013 and contains an oversample of African American and Latino respondents. 


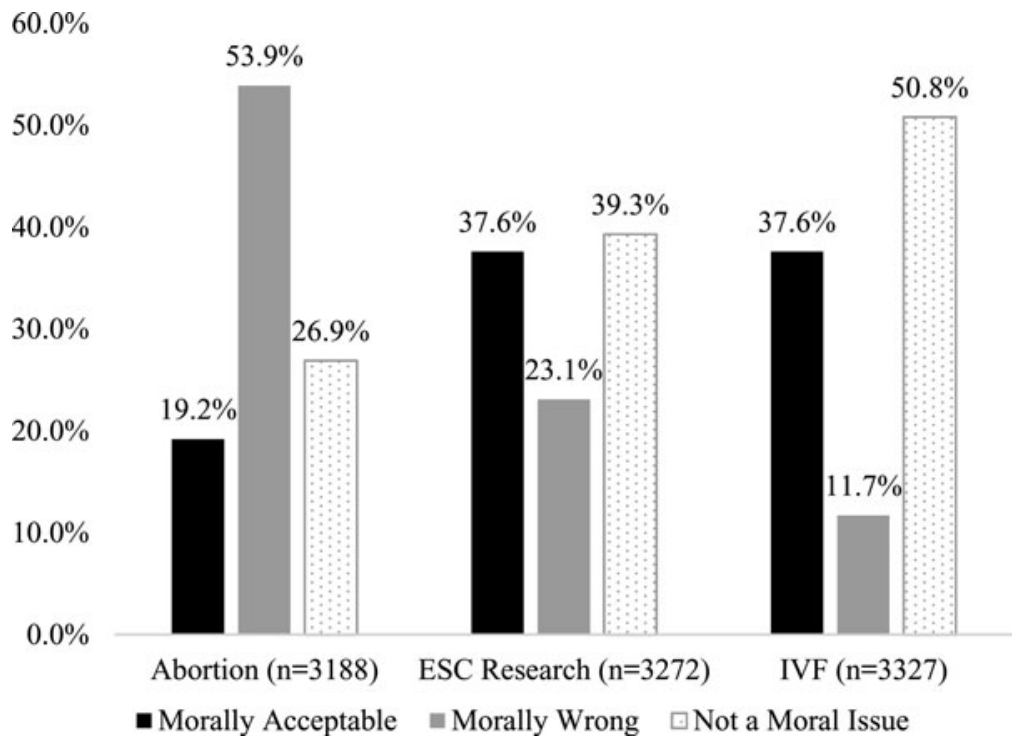

FIGURE 1. Moral attitudes toward abortion, embryonic stem cell research, and IVF. Data: Pew Research Center 2013 Survey of Aging and Longevity.

To examine whether individuals have similar attitudes about a range of policies involving human embryos, I focus specifically on responses to the following series of questions, "Do you personally believe that xx (embryonic politics procedure) is morally acceptable, morally wrong, or is not a moral issue?" I analyze responses regarding abortion, medical research that uses embryonic stem cells (ESC research), and using IVF. ${ }^{7}$ As Figure 1 illustrates, while all three policies are rooted in underlying questions about the status of the human embryo, significant differences exist in the extent to which respondents view each through a moral lens. For instance, a majority of respondents describe IVF as "not a moral issue," while only about a quarter of respondents categorize abortion in this way. Nearly $57 \%$ of respondents view abortion as morally wrong, compared with just $13 \%$ for IVF. These results support the first hypothesis and suggest that there is unlikely to be broad support for expansive fetal personhood laws that would also impact access to IVF.

Given that far more respondents oppose abortion, Figure 2 examines attitude constraints by looking specifically at whether respondents who describe abortion as morally wrong feel similarly about ESC research and IVF. As the figure demonstrates, while nearly $41 \%$ of respondents who describe abortion as morally wrong oppose ESC research, nearly 


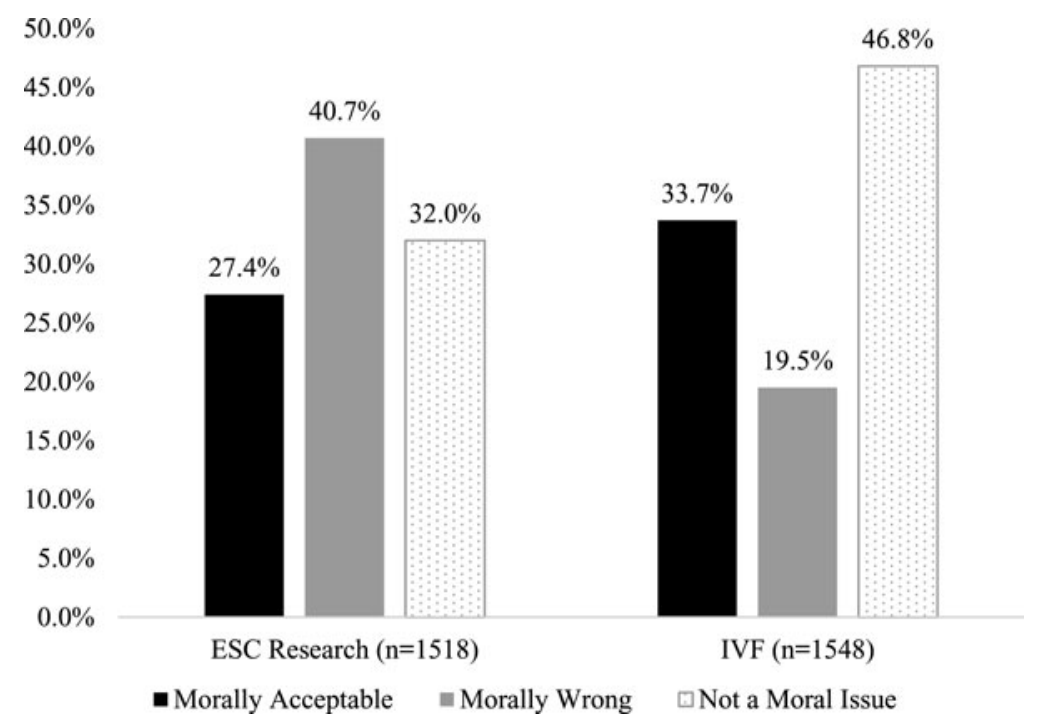

FIGURE 2. Attitudes about ESC research and IVF among respondents who think abortion is morally wrong. Data: Pew Research Center 2013 Survey of Aging and Longevity.

half of those who say abortion is morally wrong describe IVF as not a moral issue. The multivariate analysis below seeks to better understand this inconsistency.

\section{Morality Politics and Attitude Constraints}

To better understand the factors that shape attitudes about each of these procedures, as well as areas of consistency and inconsistency, I begin by examining individuals with constrained views about these embryonic policies. To do so, I conduct a multivariate analysis, dividing respondents into three categories: individuals who find all policies to be either morally wrong (0) or morally acceptable (2), compared with respondents with mixed views (1). Then, I examine each procedure separately to better understand the factors underlying these views, contrasting the results to see whether the same factors lead to opposition across policy areas.

Per $\mathrm{H} 2$ through $\mathrm{H} 4$, I expect that both religiosity and religious denomination will significantly influence an individual's views on the morality of each of these procedures, with the strongest relationship between these variables and attitudes about abortion, followed by ESC research, and 
then IVF. To capture religiosity, I include a series of dummy variables indicating how important religion is to the respondent, ranging from very important to not at all important (excluded as the reference group) (see the Appendix for a complete list of variables and coding). Another series of dummy variables measures religious denomination, including mainline Protestants (reference group), Evangelical Protestants, Catholics, and Jewish respondents, with the expectation that Evangelicals and Catholics will be more opposed to these procedures while Jews will be most accepting. I also include dummy variables for respondents who identify with the Church of Jesus Christ of Latter Day Saints (LDS/Mormons); as not religious; or with another religion, including Muslim, Buddhist, Hindu, Unitarian, and "other Christian." 8

The multivariate models also include a number of control variables, including race/ethnicity, age, gender, education, and income. With respect to gender specifically, existing research largely finds no relationship with abortion attitudes (Cook, Jelen and Wilcox 1992; Jelen and Wilcox 2003) or ESC research (Ho, Brossard and Scheufele 2008, Shih, Scheufele and Brossard 2013). In contrast, the limited scholarship on IVF finds that in the United States, women are more likely to support insurance coverage for the procedure, while cross-nationally, they are more likely to think that associated costs should be reimbursed (Adashi et al. 2000; Nachtigall, MacDougall, Davis and Beyene 2012). Similarly, I anticipate that women will be more likely to consider IVF morally acceptable. Given the cost barriers to IVF, and perceptions that it is primarily an upper-class phenomenon (Bell 2009), I anticipate that socioeconomic status will play a greater role in IVF attitudes compared with other embryonic policy areas. In the models that follow, income is measured as a series of dummy variables (under $\$ 30,000$ (reference group); $\$ 30,000-50,000$; $\$ 50,000-75,000 ; \$ 75,000-100,000$; and over $\$ 100,000)$, while education is measured continuously. I include an additional control variable for marital status with the expectation that married respondents will be more likely to describe abortion as morally wrong and IVF as morally acceptable.

Because ideology and partisanship are not always consistent, I include dummy variables for both partisanship (Democrat, Republican, and independent, with independent as the reference group) and ideology (conservative, liberal, and moderate, with moderate as the reference group), with the expectation that respondents who are Republican and more conservative will be more likely to oppose these procedures, and particularly abortion, while liberals and Democrats will be more accepting. 
Table 1. Multinomial regression results: are all three embryonic policies morally unacceptable/morally acceptable (compared with mixed views on different policies)?

\section{All morally wrong}

All morally acceptable

Religiosity

Very important

$2.05^{*}$

$(0.87)$

Somewhat important

$1.69^{\wedge}$

$(0.91)$

$-0.35$

Not too important

0.73

(0.98)

(0.35)

$-0.063$

(0.31)

0.27

(0.31)

Denomination

Evangelical Protestant

$1.33 * * *$

$-0.66 *$

(0.39)

Catholic

0.79

(0.32)

$-0.42$

(0.45)

LDS

$-13.84 * * *$

(0.45)

Jewish

0.84

(1.15)

(0.29)

$-13.83 * * *$

(0.34)

$-0.03$

(0.47)

Not religious

$0.90^{\wedge}$

0.45

$(0.55)$

Other religion

$-0.06$

(0.31)

(0.73)

0.15

(0.38)

Demographics

Female

$-0.20$

$-0.34$

Married

(0.22)

(0.20)

0.22

$-0.10$

(0.26)

(0.20)

African American

$-0.33$

$-0.29$

(0.347)

(0.29)

Latino

0.68 *

$-0.20$

$(0.31)$

(0.29)

Other race

0.54

(0.43)

$-0.66$

(0.40)

Age

0.01

(0.06)

$0.12 * *$

$(0.05)$

Education

$-0.05$

(0.05)

0.05

(0.04)

Ideology/partisanship

Conservative

$0.52 *$

$-0.75^{*}$

(0.24)

(0.30)

Liberal

$-1.17 * *$

0.05

(0.39)

$(0.21)$

Democrat

0.13

$0.56^{* *}$

Republican

$(0.25)$

(0.21)

0.07

$-0.11$

(0.28)

(0.30) 
Table 1. Continued

\begin{tabular}{lcc}
\hline & All morally wrong & All morally acceptable \\
\hline Income & & \\
$\$ 30,000-50,000$ & $-0.72 *$ & -0.20 \\
& $(0.31)$ & $(0.32)$ \\
$\$ 50,000-75,000$ & $-0.84^{*}$ & 0.48 \\
& $(0.40)$ & $(0.30)$ \\
$\$ 75,000-100,000$ & -0.30 & 0.31 \\
& $(0.37)$ & $(0.34)$ \\
$>\$ 100,000$ & $-1.07 *$ & 0.45 \\
& $(0.44)$ & $(0.30)$ \\
Constant & $-4.44^{* * *}$ & $-3.10^{* * *}$ \\
& $(1.11)$ & $(0.72)$ \\
Observations & 2,660 & 2,660 \\
Pseudo $R^{2}$ & 0.134 & 0.134 \\
\hline
\end{tabular}

Robust standard errors are in parentheses. Significance levels: ${ }^{\wedge} p<0.10,{ }^{*} p<0.05,{ }^{* *} p<0.01,{ }^{* * *} p<$ 0.001 .

\section{Consistent Attitudes about Embryonic Policies}

The first analysis seeks to understand the factors that are associated with constrained attitudes about embryonic policies, including respondents with the most consistent attitudes in either direction. Because morally acceptable, morally wrong, and not a moral issue cannot be clearly ordered, Table 1 presents the results of a multinomial logistic regression analysis comparing respondents who have mixed attitudes about the three procedures (baseline) with respondents who consider all three procedures to be either morally wrong (column 1) or morally acceptable (column 2). As multinomial logit coefficients are difficult to interpret, marginal effects for all statistically significant variables are included in the appendix (see Table B1). ${ }^{9}$

Consistent with $\mathrm{H} 2$, individuals who consider religion to be very important are more likely to describe all three policies as morally wrong. However, there is no statistically significant relationship between religiosity and consistently describing the procedures as morally acceptable. Religiosity clearly shapes moral opposition to-but not support for-embryonic politics. Compared with mainline Protestants, Evangelical Protestants hold more constrained views, being nine percentage points more likely to describe all three procedures as morally wrong and five percentage points less likely to describe them as morally acceptable. Despite expectations that Catholic respondents would similarly be opposed to all three procedures, while Jewish respondents would be 
more accepting, these variables do not reach statistical significance in the first model. Interestingly, in comparison with mainline Protestants, LDS respondents are less likely to have constrained attitudes, being less likely to describe all three procedures as both morally acceptable and morally unacceptable. As discussed below, the LDS anomaly is likely the result of higher levels of support for IVF within this community. Yet, the small sample size of LDS $(n=51)$ respondents suggests that these results should be interpreted with caution.

Consistent with existing research demonstrating that Latinos hold more conservative views on abortion and other family-related issues (Leal 2007; Abrajano and Alvarez 2010; Gibson and Hare 2012), Latino respondents are significantly more likely to oppose all three procedures. Demonstrating the importance of ideology, compared with moderates, conservative respondents are more likely to describe all three policies as morally wrong, while liberals are less likely to do so. Similarly, conservatives are less likely to describe all three policies as morally acceptable, while in comparison to independents, Democrats are more likely to do so, yet the substantive effects of these variables are weak in comparison to the religion variables. Other control variables also have significant effects. For instance, older respondents are more likely to describe all three procedures as morally acceptable, and respondents with higher incomes are less likely to describe them as morally wrong.

The above analysis finds support for $\mathrm{H} 2$ and parts of $\mathrm{H} 3$, demonstrating a relationship between religiosity and Evangelical Protestantism with constrained attitudes opposing embryonic policies. Yet, these results do not provide the opportunity to compare the extent to which the same factors influence attitudes about specific procedures. Next, I examine public opinion toward each procedure separately. Table 2 presents results of three multinomial logit models with attitudes about abortion, ESC research, and IVF included as distinct dependent variables. The models compare respondents who describe each policy as morally wrong (0) or morally acceptable (2) with a baseline of respondents who say it is not a moral issue (1). Given that I am most interested in understanding whether or not respondents consistently oppose these procedures, and the extent to which religion and religiosity influences this moral view, the discussion below will focus primarily on those results.

Looking across the models, the strength of the religiosity variable is clear; across all policy areas, respondents who describe religion as a very important part of their lives are more likely to describe a procedure that involves the destruction of embryos as morally wrong. Figure 3 presents 
Table 2. Multinomial regression, are abortion, ESC research, and IVF morally wrong or morally acceptable (compared with not a moral issue)

\begin{tabular}{|c|c|c|c|c|c|c|}
\hline & \multicolumn{2}{|c|}{ Abortion } & \multicolumn{2}{|c|}{ ESC research } & \multicolumn{2}{|c|}{ IVF } \\
\hline & $\begin{array}{c}\text { (1) } \\
\text { Morally } \\
\text { wrong }\end{array}$ & $\begin{array}{c}(2) \\
\text { Morally } \\
\text { acceptable }\end{array}$ & $\begin{array}{c}\text { (3) } \\
\text { Morally } \\
\text { wrong }\end{array}$ & $\begin{array}{c}\text { (4) } \\
\text { Morally } \\
\text { acceptable }\end{array}$ & $\begin{array}{c}(5) \\
\text { Morally } \\
\text { wrong }\end{array}$ & $\begin{array}{c}(6) \\
\text { Morally } \\
\text { acceptable }\end{array}$ \\
\hline \multicolumn{7}{|l|}{ Religiosity } \\
\hline Very important & $\begin{array}{l}1.46^{* * * *} \\
(0.29)\end{array}$ & $\begin{array}{c}-0.15 \\
(0.27)\end{array}$ & $\begin{array}{l}1.22 * * \\
(0.42)\end{array}$ & $\begin{array}{c}0.31 \\
(0.22)\end{array}$ & $\begin{array}{l}1.39 * * * \\
(0.43)\end{array}$ & $\begin{array}{c}0.24 \\
(0.22)\end{array}$ \\
\hline Somewhat important & $\begin{array}{c}0.41 \\
(0.29)\end{array}$ & $\begin{array}{c}-0.31 \\
(0.25)\end{array}$ & $\begin{array}{c}0.63 \\
(0.42)\end{array}$ & $\begin{array}{c}0.21 \\
(0.22)\end{array}$ & $\begin{array}{c}0.86^{*} \\
(0.44)\end{array}$ & $\begin{array}{c}0.25 \\
(0.22)\end{array}$ \\
\hline Not too important & $\begin{array}{c}-0.07 \\
(0.34)\end{array}$ & $\begin{array}{c}-0.07 \\
(0.27)\end{array}$ & $\begin{array}{c}-0.16 \\
(0.46)\end{array}$ & $\begin{array}{c}0.11 \\
(0.24)\end{array}$ & $\begin{array}{c}0.66 \\
(0.50)\end{array}$ & $\begin{array}{c}0.37 \\
(0.24)\end{array}$ \\
\hline \multicolumn{7}{|l|}{ Denomination } \\
\hline Evangelical Protestant & $\begin{array}{l}0.89 * * * \\
(0.22)\end{array}$ & $\begin{array}{c}-0.17 \\
(0.28)\end{array}$ & $\begin{array}{l}0.79 * * * \\
(0.24)\end{array}$ & $\begin{array}{c}-0.13 \\
(0.20)\end{array}$ & $\begin{array}{c}0.21 \\
(0.30)\end{array}$ & $\begin{array}{c}-0.24 \\
(0.18)\end{array}$ \\
\hline Catholic & $\begin{array}{c}0.35 \\
(0.21)\end{array}$ & $\begin{array}{c}-0.31 \\
(0.26)\end{array}$ & $\begin{array}{c}0.33 \\
(0.25)\end{array}$ & $\begin{array}{c}-0.14 \\
(0.20)\end{array}$ & $\begin{array}{c}-0.04 \\
(0.31)\end{array}$ & $\begin{array}{c}-0.29 \\
(0.18)\end{array}$ \\
\hline LDS & $\begin{array}{c}0.41 \\
(0.55)\end{array}$ & $\begin{array}{c}-0.53 \\
(0.78)\end{array}$ & $\begin{array}{c}0.13 \\
(0.55)\end{array}$ & $\begin{array}{c}0.28 \\
(0.52)\end{array}$ & $\begin{array}{c}-1.44^{\wedge} \\
(0.76)\end{array}$ & $\begin{array}{c}0.91 * \\
(0.42)\end{array}$ \\
\hline Jewish & $\begin{array}{c}-1.03^{*} \\
(0.50)\end{array}$ & $\begin{array}{c}-0.37 \\
(0.45)\end{array}$ & $\begin{array}{c}-0.45 \\
(0.62)\end{array}$ & $\begin{array}{c}-0.27 \\
(0.38)\end{array}$ & $\begin{array}{c}0.30 \\
(0.67)\end{array}$ & $\begin{array}{c}-0.56 \\
(0.36)\end{array}$ \\
\hline Not religious & $\begin{array}{c}-0.23 \\
(0.26)\end{array}$ & $\begin{array}{c}0.03 \\
(0.26)\end{array}$ & $\begin{array}{c}0.16 \\
(0.34)\end{array}$ & $\begin{array}{c}0.27 \\
(0.21)\end{array}$ & $\begin{array}{c}0.28 \\
(0.37)\end{array}$ & $\begin{array}{c}0.07 \\
(0.21)\end{array}$ \\
\hline Other religion & $\begin{array}{c}-0.02 \\
(0.29)\end{array}$ & $\begin{array}{c}-0.23 \\
(0.32)\end{array}$ & $\begin{array}{c}0.02 \\
(0.35)\end{array}$ & $\begin{array}{c}-0.02 \\
(0.25)\end{array}$ & $\begin{array}{c}-0.06 \\
(0.41)\end{array}$ & $\begin{array}{c}-0.20 \\
(0.23)\end{array}$ \\
\hline
\end{tabular}


Table 2. Continued

\begin{tabular}{|c|c|c|c|c|c|c|}
\hline & \multicolumn{2}{|c|}{ Abortion } & \multicolumn{2}{|c|}{ ESC research } & \multicolumn{2}{|c|}{ IVF } \\
\hline & $\begin{array}{c}\text { (1) } \\
\text { Morally } \\
\text { wrong }\end{array}$ & $\begin{array}{c}(2) \\
\text { Morally } \\
\text { acceptable }\end{array}$ & $\begin{array}{c}\text { (3) } \\
\text { Morally } \\
\text { wrong }\end{array}$ & $\begin{array}{c}\text { (4) } \\
\text { Morally } \\
\text { acceptable }\end{array}$ & $\begin{array}{c}\text { (5) } \\
\text { Morally } \\
\text { wrong }\end{array}$ & $\begin{array}{c}(6) \\
\text { Morally } \\
\text { acceptable }\end{array}$ \\
\hline \multicolumn{7}{|l|}{ Demographics } \\
\hline Female & $\begin{array}{c}-0.25^{\wedge} \\
(0.14)\end{array}$ & $\begin{array}{c}-0.46^{* *} \\
(0.16)\end{array}$ & $\begin{array}{c}-0.19 \\
(0.14)\end{array}$ & $\begin{array}{c}-0.14 \\
(0.12)\end{array}$ & $\begin{array}{c}-0.34^{*} \\
(0.16)\end{array}$ & $\begin{array}{c}0.19^{\wedge} \\
(0.11)\end{array}$ \\
\hline Married & $\begin{array}{l}0.51^{* * *} \\
(0.15)\end{array}$ & $\begin{array}{c}0.04 \\
(0.16)\end{array}$ & $\begin{array}{c}0.13 \\
(0.16)\end{array}$ & $\begin{array}{c}0.11 \\
(0.13)\end{array}$ & $\begin{array}{c}0.19 \\
(0.19)\end{array}$ & $\begin{array}{c}0.14 \\
(0.12)\end{array}$ \\
\hline African American & $\begin{array}{c}-0.09 \\
(0.22)\end{array}$ & $\begin{array}{c}-0.02 \\
(0.24)\end{array}$ & $\begin{array}{c}-0.38^{\wedge} \\
(0.22)\end{array}$ & $\begin{array}{c}-0.41 * \\
(0.18)\end{array}$ & $\begin{array}{c}-0.07 \\
(0.26)\end{array}$ & $\begin{array}{c}-0.50 * * \\
(0.18)\end{array}$ \\
\hline Latino & $\begin{array}{c}0.13 \\
(0.19)\end{array}$ & $\begin{array}{c}-0.16 \\
(0.24)\end{array}$ & $\begin{array}{c}0.09 \\
(0.20)\end{array}$ & $\begin{array}{c}-0.18 \\
(0.18)\end{array}$ & $\begin{array}{l}0.65 * * \\
(0.22)\end{array}$ & $\begin{array}{c}-0.07 \\
(0.17)\end{array}$ \\
\hline Other race & $\begin{array}{c}-0.31 \\
(0.27)\end{array}$ & $\begin{array}{c}-0.32 \\
(0.30)\end{array}$ & $\begin{array}{c}0.30 \\
(0.26)\end{array}$ & $\begin{array}{c}-0.33 \\
(0.25)\end{array}$ & $\begin{array}{c}0.66^{*} \\
(0.31)\end{array}$ & $\begin{array}{c}-0.14 \\
(0.23)\end{array}$ \\
\hline Decade & $\begin{array}{c}-0.08^{\wedge} \\
(0.04)\end{array}$ & $\begin{array}{c}0.02 \\
(0.05)\end{array}$ & $\begin{array}{c}-0.06 \\
(0.04)\end{array}$ & $\begin{array}{c}0.07 * \\
(0.04)\end{array}$ & $\begin{array}{c}0.09^{\wedge} \\
(0.05)\end{array}$ & $\begin{array}{c}0.04 \\
(0.03)\end{array}$ \\
\hline Education & $\begin{array}{c}0.00 \\
(0.03)\end{array}$ & $\begin{array}{c}0.03 \\
(0.03)\end{array}$ & $\begin{array}{c}-0.00 \\
(0.03)\end{array}$ & $\begin{array}{c}0.03 \\
(0.02)\end{array}$ & $\begin{array}{c}-0.04 \\
(0.04)\end{array}$ & $\begin{array}{c}0.02 \\
(0.02)\end{array}$ \\
\hline \multicolumn{7}{|l|}{ Ideology/partisanship } \\
\hline Conservative & $\begin{array}{l}0.84 * * * \\
(0.17)\end{array}$ & $\begin{array}{c}0.20 \\
(0.24)\end{array}$ & $\begin{array}{l}0.47 * * \\
(0.17)\end{array}$ & $\begin{array}{c}-0.03 \\
(0.15)\end{array}$ & $\begin{array}{c}0.51 * \\
(0.20)\end{array}$ & $\begin{array}{c}0.03 \\
(0.13)\end{array}$ \\
\hline Liberal & $\begin{array}{c}-0.36^{*} \\
(0.17)\end{array}$ & $\begin{array}{c}0.18 \\
(0.18)\end{array}$ & $\begin{array}{c}-0.36^{\wedge} \\
(0.20)\end{array}$ & $\begin{array}{c}0.05 \\
(0.14)\end{array}$ & $\begin{array}{c}-0.55^{*} \\
(0.24)\end{array}$ & $\begin{array}{c}-0.28^{*} \\
(0.14)\end{array}$ \\
\hline Democrat & $\begin{array}{c}-0.40^{*} \\
(0.16)\end{array}$ & $\begin{array}{c}0.44^{*} \\
(0.18)\end{array}$ & $\begin{array}{c}-0.27 \\
(0.18)\end{array}$ & $\begin{array}{c}0.31^{*} \\
(0.14)\end{array}$ & $\begin{array}{c}0.14 \\
(0.20)\end{array}$ & $\begin{array}{l}0.38 * * \\
(0.13)\end{array}$ \\
\hline Republican & $\begin{array}{c}0.19 \\
(0.20)\end{array}$ & $\begin{array}{c}-0.33 \\
(0.26)\end{array}$ & $\begin{array}{c}0.45^{*} \\
(0.18)\end{array}$ & $\begin{array}{c}0.20 \\
(0.17)\end{array}$ & $\begin{array}{c}-0.21 \\
(0.23)\end{array}$ & $\begin{array}{c}0.12 \\
(0.15)\end{array}$ \\
\hline
\end{tabular}


Table 2. Continued

\begin{tabular}{|c|c|c|c|c|c|c|}
\hline & \multicolumn{2}{|c|}{ Abortion } & \multicolumn{2}{|c|}{ ESC research } & \multicolumn{2}{|c|}{ IVF } \\
\hline & $\begin{array}{c}\text { (1) } \\
\text { Morally } \\
\text { wrong }\end{array}$ & $\begin{array}{c}\text { (2) } \\
\text { Morally } \\
\text { acceptable }\end{array}$ & $\begin{array}{c}(3) \\
\text { Morally } \\
\text { wrong }\end{array}$ & $\begin{array}{c}\text { (4) } \\
\text { Morally } \\
\text { acceptable }\end{array}$ & $\begin{array}{c}\text { (5) } \\
\text { Morally } \\
\text { wrong }\end{array}$ & $\begin{array}{c}\text { (6) } \\
\text { Morally } \\
\text { acceptable }\end{array}$ \\
\hline \multicolumn{7}{|l|}{ Income } \\
\hline$\$ 30,000-50,000$ & $\begin{array}{c}-0.88 * * * \\
(0.19)\end{array}$ & $\begin{array}{c}-0.62 * * \\
(0.24)\end{array}$ & $\begin{array}{c}-0.19 \\
(0.20)\end{array}$ & $\begin{array}{r}-0.16 \\
(0.17)\end{array}$ & $\begin{array}{c}-0.67 * * \\
(0.22)\end{array}$ & $\begin{array}{r}-0.01 \\
(0.16)\end{array}$ \\
\hline$\$ 50,000-75,000$ & $\begin{array}{c}-0.75 * * * \\
(0.23)\end{array}$ & $\begin{array}{c}0.03 \\
(0.25)\end{array}$ & $\begin{array}{c}-0.48 * \\
(0.24)\end{array}$ & $\begin{array}{c}-0.06 \\
(0.19)\end{array}$ & $\begin{array}{c}-0.83 * * \\
(0.30)\end{array}$ & $\begin{array}{c}0.29 \\
(0.18)\end{array}$ \\
\hline$\$ 75,000-100,000$ & $\begin{array}{c}-0.85 * * * \\
(0.23)\end{array}$ & $\begin{array}{c}0.04 \\
(0.28)\end{array}$ & $\begin{array}{c}-0.13 \\
(0.24)\end{array}$ & $\begin{array}{c}-0.08 \\
(0.21)\end{array}$ & $\begin{array}{c}-0.53^{\wedge} \\
(0.29)\end{array}$ & $\begin{array}{c}0.13 \\
(0.19)\end{array}$ \\
\hline$>\$ 100,000$ & $\begin{array}{c}-0.93 * * * \\
(0.22)\end{array}$ & $\begin{array}{c}0.17 \\
(0.25)\end{array}$ & $\begin{array}{c}-0.71 * * \\
(0.22)\end{array}$ & $\begin{array}{c}-0.08 \\
(0.19)\end{array}$ & $\begin{array}{c}-0.87 * * \\
(0.30)\end{array}$ & $\begin{array}{c}0.19 \\
(0.18)\end{array}$ \\
\hline Constant & $\begin{array}{c}0.16 \\
(0.55)\end{array}$ & $\begin{array}{c}-0.56 \\
(0.57)\end{array}$ & $\begin{array}{c}-1.40 * * \\
(0.66)\end{array}$ & $\begin{array}{c}-0.92^{\wedge} \\
(0.47)\end{array}$ & $\begin{array}{l}-2.20 * * \\
(0.76)\end{array}$ & $\begin{array}{l}-1.17 * * \\
(0.45)\end{array}$ \\
\hline Observations & 2,827 & 2,827 & 2,908 & 2,908 & 2,954 & 2,954 \\
\hline Prob $>\chi^{2}$ & 0.00 & 0.00 & 0.00 & 0.00 & 0.00 & 0.00 \\
\hline Pseudo $R^{2}$ & 0.19 & 0.19 & 0.07 & 0.07 & 0.05 & 0.05 \\
\hline
\end{tabular}

Robust standard errors are in parentheses. Significance levels: ${ }^{\wedge} p<0.1,{ }^{*} p<0.05,{ }^{*} p<0.01,{ }^{*} * p<0.001$. 
(a)

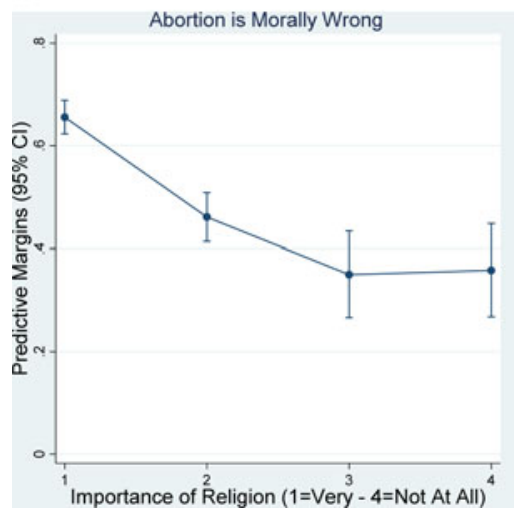

(b)

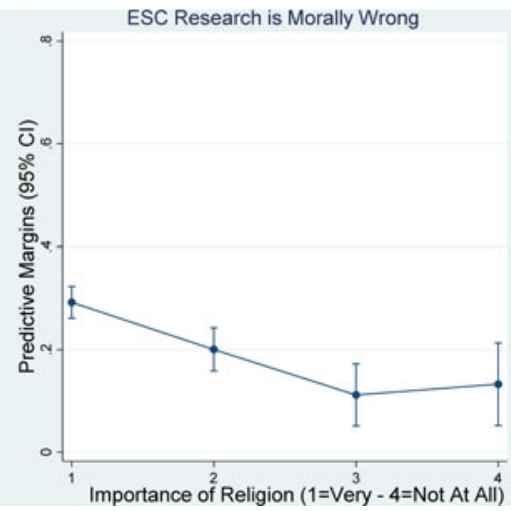

(c)

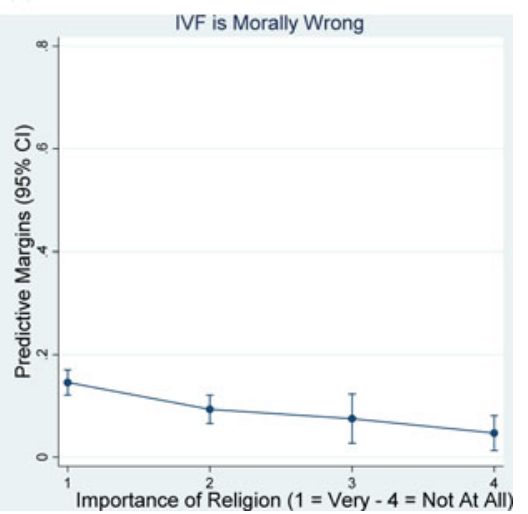

FIGURE 3. (Color online) Marginal effect of religiosity on public opinion that abortion, ESC research, and IVF are morally wrong. 
the marginal effects of describing oneself as very religious on attitudes toward the morality of each of the embryonic politics procedures. As the graphs in Figure 3 demonstrate, while there is a statistically significant relationship between religiosity and attitudes toward each of these procedures, as anticipated, the substantive effects are strongest with respect to abortion attitudes; compared with respondents who say religion is not at all important, those who say religion is very important are 30 percentage points more likely to characterize abortion as morally wrong, a dramatic shift. By contrast, respondents who are most religious are 16 percentage points more likely to categorize ESC research as morally wrong, and 10 percentage points more likely to do so for IVF. As Figure 3 demonstrates, the difference is most dramatic among the first two categories (religion being very important and somewhat important), with little difference in the latter categories (religion is not too important or not at all important).

H3 anticipates that, compared with mainline Protestants, Evangelical Protestants and Catholics will be more likely to describe these procedures as morally wrong, while Jews will find them morally acceptable, while $\mathrm{H} 4$ anticipates that the relationship between denomination and embryonic politics attitudes will be strongest with abortion and weakest with IVF. These results demonstrate partial support for this hypothesis. Evangelical Protestants are more likely to describe both abortion (17 percentage points) and ESC research (14 percentage points) as morally wrong, and again these results are both statistically and substantively significant. Even as Table 1 demonstrates more constrained attitudes across policy areas for Evangelical Protestants, surprisingly, the relationship between this variable and IVF attitudes is not statistically significant. In contrast to expectations that Catholics would be more likely to find these procedures unacceptable while Jewish respondents would find them more acceptable, in most cases, these variables are not statistically significant; the only exception is that Jewish respondents are more open to abortion. Because I am most interested in understanding which respondents describe these procedures as morally wrong, as a robustness check, I ran the models using logistic regression, where $1=$ morally wrong and $0=$ morally acceptable/not a moral issue. In this analysis, Catholics are more likely to oppose abortion while the variable for Jewish respondents becomes marginally significant (see Appendix Table B9). Surprisingly, LDS respondents are not more likely to oppose abortion or ESC research, but they are more likely to describe IVF as morally acceptable, and marginally less likely to describe IVF as morally unacceptable $(p<0.006)$. Although church guidelines oppose abortion in most cases, the church notes that 
with respect to IVF "(r)esponsibility for the decision rests solely upon" a husband and wife, meaning that this distinction is not driven by the church doctrine (The Church of Jesus Christ of Latter-Day Saints ND). The emphasis placed by the church on large families may contribute to more open attitudes about this procedure. Again, given the small sample size of LDS respondents, these results should be interpreted with caution, but this unexpected finding underscores that in addition to religion, ideas about the role of science in reproduction and other norms are also likely to influence attitudes about IVF.

Compared with the baseline category of not a moral issue, women are less likely to describe abortion as morally acceptable, but they are also less likely to describe it as morally wrong, though the latter relationship is only marginally significant. Notably, while Scott (1989) finds gendered differences in attitudes about the morality of abortion, these differences disappear in response to questions about abortion policy. There are no gendered differences in opinion about ESC research. Women are less likely to describe IVF as morally wrong and more likely to describe it as morally acceptable, though the latter result exceeds conventional measures of statistical significance. This result is particularly interesting in light of divisions within feminist groups about IVF, and ARTs more generally (Heidt-Forsythe 2013). While attitudes about gender roles are also thought to interact with religious beliefs (Cassese and Holman 2017), unfortunately, there is no variable included in the dataset to measure these views.

Although African Americans and Latinos have traditionally been more pro-life than white respondents (Combs and Welch 1982; Uhlaner and Garcia 2002; Jelen and Wilcox 2003; Leal 2007), some research suggests that the racial attitudes gap between Whites and African Americans may have shifted. Others find that variation in racial attitudes may be contingent upon religiosity (Strickler and Danigelis 2002; Carter, Carter and Dodge 2009) or gender (Combs and Welch 1982; Wilcox 1990). Across racial and ethnic groups, I find no difference in attitudes about abortion. Yet, African-American respondents are less likely to indicate that ESC research or IVF is morally acceptable, while Latinos are more likely to describe IVF as morally wrong. ${ }^{10}$ Recall that in Table 1, Latinos are more likely to consistently oppose all three procedures. These results suggest that greater opposition to IVF among Latinos drive this high level of constraint. ${ }^{11}$ Compared with white respondents, individuals identifying with another race are also more likely to describe IVF as morally unacceptable. Unfortunately, little information is known about the background of individuals in this category, but these findings point to the 
need for further research on variation in attitudes about a range of embryonic policies by race/ethnicity.

Despite my expectations of a stronger relationship between income and IVF, as compared with abortion or ESC research, I find that the opposite is the case. In general, individuals in the highest income category are less likely to view all three procedures as morally wrong, but the relationship is strongest $(-0.18)$ with respect to abortion and weakest $(-0.09)$ for IVF.

The results in Table 2 also reiterate the important role of ideology in morality politics. Respondents who describe themselves as conservative are significantly more likely to describe each of the three procedures as morally wrong, and liberals are less likely to do so, though the results for ESC research are only marginally significant. Existing research demonstrates strong partisan polarization surrounding abortion and stem cell research (Adams 1997; Jelen and Wilcox 2003; Hillygus and Shields 2014). I find that Democrats are more likely to describe all three procedures as morally acceptable and are less likely to describe abortion as morally wrong. Surprisingly, the dummy variable for Republicans is significant only for ESC research. Consistent with higher rates of abortion among unmarried women, married respondents are also more likely to describe abortion as morally unacceptable. In contrast, the absence of a relationship between marital status and attitudes about IVF is unexpected.

Given the relatively low levels of debate surrounding IVF, it is possible that some respondents indicating IVF is not a moral issue are unfamiliar with the specifics of the procedure and that embryos may be destroyed in the process. Unfortunately, in the present survey, no follow-up questions were asked that would provide the opportunity to gauge respondents' knowledge about IVF. Notably, the sample size is largest with respect to the IVF question, suggesting that at a minimum, people's lack of familiarity did not prevent them from answering questions about the procedure. In light of the lack of research surrounding public opinion on IVF, my findings represent an important step in improving our understanding of attitudes about this procedure. One important avenue for future research would be to better understand people's underlying knowledge about IVF and the way that this may influence attitudes about its morality.

\section{CONCLUSION}

In this paper, I seek to understand whether individuals hold consistent views regarding policies that involve the disposal of human embryos. Given the 
role of religion in influencing attitudes and beliefs about the status of embryos, I focus in particular on the varying roles of religiosity and religious denomination in shaping public opinion about the morality of abortion, ESC research, and IVF. I demonstrate considerable differences in popular opinion around these policy areas. Individuals who say religion is very important in their life and Evangelical Protestants are more likely to hold constrained attitudes, consistently characterizing these procedures as morally wrong. The most devout respondents are also more likely to oppose each individual policy, with the strongest relationship between abortion and the weakest with IVF. At the same time, other indicators of religion yield more surprising results. For instance, no relationship exists between Evangelical Protestants and IVF attitudes. Additionally, while the Catholic Church has been outspoken in opposition to procedures regarding human embryos, in comparison with mainline Protestants, I find that Catholics are no more likely to describe these procedures as morally wrong. Likewise, despite expectations that Jewish respondents would hold the most liberal views about embryonic politics, this variable was significant only for views on abortion.

My results demonstrate that the influence of religious denomination in shaping attitudes about embryonic policies is inconsistent, and may be mitigated by the objective of each procedure. These results align with previous scholarship arguing that in contrast to abortion, with the objective of ending a human life, the goals of ESC research-improving and extending individuals' well-being through medical research-may counterbalance concerns about the destruction of embryos (Dolgin, Fisher and Shapiro 2008). In this paper, I extend this argument by also examining attitudes about IVF, a procedure that has the larger objective of creating new life. Although embryos may also be destroyed in this procedure, the end goal arguably alters the moral calculus for many individuals, even among some Evangelical respondents who are strong abortion opponents.

Beyond religion, the findings that Latino respondents are more likely to oppose IVF, and LDS respondents are less likely to do so, are somewhat counterintuitive results that warrant further study. In contrast to abortion and ESC research, which have each become polarizing issues, IVF has been far less politicized. Likewise, the relationship between partisanship and moral opposition to IVF is weaker, compared with abortion or ESC research.

Given the dearth of current research about attitudes toward IVF in particular, my results significantly improve our understanding of public opinion on this issue. In the nearly four decades that have passed since the NIH's controversial report linking IVF to abortion, I find that this 


\section{association no longer seems to be the case. Rather, I demonstrate that respondents are far more likely to moderate their views on embryonic pol- itics matters depending on the outcome, with individuals significantly more accepting of procedures that seek to improve or create human life.}

\section{NOTES}

1. For a comprehensive history of stem cell policy, see Nisbet, Brossard, and Kroepsch (2003) and Johnson and Liu (2012).

2. In recent years, scientists have induced pluripotent stem cells in the absence of human embryos, leading some to describe the controversy over ESC research as "moot," as human embryos are no longer required. However, others argue that embryonic stem cells remain superior, and are the gold standard for research (Thompson 2013).

3. While the terms embryo and fetus are frequently conflated, technically, the embryonic stage of development lasts from fertilization of an egg until 8 weeks of gestation, at which period the embryo is referred to as the fetus. Unlike abortion, ESC research is limited to only embryos.

4. Recommendations surrounding how many embryos to implant depend on a combination of factors, including age, the apparent health of the embryo prior to implantation, and previous success with IVF.

5. Selective reduction is most often practiced in cases where a woman is pregnant with three or more fetuses. While the percentage of twins and triplets initially rose dramatically as a result of ARTs, these numbers began to decrease in the 2000s doctors as implanted fewer numbers of embryos, and the number of cases of selective reduction increased (The American College of Obstetricians and Gynecologists, 2013).

6. The Pew Research Center bears no responsibility for the interpretations presented or conclusions reached based on the analysis of the data.

7. Notably, moral opposition is not always equivalent to policy opposition; for instance, Scott and Schuman (1988) find that roughly a quarter of respondents who support abortion rights find abortion to be morally objectionable, with this discrepancy larger among women than men.

8. Using binary variables for religious denomination is consistent with existing research exploring the relationship between religion and public opinion. Evangelical Protestant includes respondents who identify as Protestant or other Christian and describe themselves as "born-again" or Evangelical, while mainline Protestants include those in the former category but not the latter (Gershon et al. 2016, Wald and Calhoun-Brown 2011). Ideally, religious denomination would have been measured using the religious traditions, or "RELTRAD," classification, which differentiates between six categories: mainline Protestant, Evangelical Protestant, Black Protestant, Roman Catholic, Jewish, and other (Steensland et al. 2000, Stetzer and Burge 2016). The RELTRAD measure was developed using data from the General Social Survey, which includes detailed questions about subspecifications of congregations within broader categories of religious traditions. Unfortunately, the Pew dataset lacks such specific questions. Thus, while I am able to differentiate between broad categories of religious traditions, and I can control for race/ethnicity, I am unable to distinguish between members of mainline Protestant and Black Protestant churches. Moreover, the RELTRAD categorization places LDS respondents in the "other" category. I discuss this group separately to highlight some of the unique trends within this denomination.

9. Analysis is done using Stata 14, with marginal effects calculated using the margins command.

10. In the logistic regression analysis, there is no statistically significant relationship between African Americans and attitudes about ESC research or IVF, nor is there a relationship between gender and abortion attitudes (see the Appendix).

11. Existing research finds that although African-American men hold more conservative views on abortion than white men, African-American women report more liberal abortion attitudes than white women (Wilcox 1990), while no gender differences exist among Latinos (Bejarano 2013). I also ran separate analyses interacting both African American and Latino with gender, but across models the interaction terms failed to reach statistical significance (see the Appendix). 


\section{REFERENCES}

Abrajano, Marisa A., and Ricardo M. Alvarez. 2010. New Faces, New Voices: The Hispanic Electorate in America. Princeton, NJ: Princeton University Press.

Adams, Greg. 1997. "Abortion: Evidence of an Issue Evolution." American Journal of Political Science 41:718-737.

Adashi, E. Y., J. Cohen, L. Hamberger, H. W. Jones, Jr., D. M. De Kretser, B. Lunenfeld, Z. Rosenwaks, and A. Van Steirteghem. 2000. "Public Perception on Infertility and its Treatment: An International Survey. The Bertarelli Foundation Scientific Board." Human Reproduction 15(2): 330-334.

American Society for Reproductive Medicine. Q06: Is In Vitro Fertilization Expensive. https://www.asrm.org/detail.aspx?id=3023. ND.

Bancoff, Thomas. 2011. Embryo Politics: Ethics and Policy in Atlantic Democracies. Ithaca, NY: Cornell University Press.

Bejarano, Christina. 2013. The Latino Gender Gap. New York: Routledge.

Bell, Ann V. 2009. ““It's Way out of my League”: Low-Income Women's Experiences of Medicalized Infertility." Gender and Society 23(5):688-709.

Bonnicksen, Andrea L. 1989. In Vitro Fertilization: Building Policy from Laboratories to Legislatures. New York: Columbia University Press.

Carter, J. Scott, Shannon Carter, and Jamie Dodge. 2009. "Trends in Abortion Attitudes by Race and Gender: A Reassessment Over A Four-Decade Period." Journal of Sociological Research 1(1):1-7.

Cassese, Erin C., and Mirya R. Holman. 2017. "Religion, Gendered Authority, and Identity in American Politics." Politics and Religion 10(1):31-56.

Centers for Disease Control. "Assisted Reproductive Technology (ART) Data." Accessed May 15, 2017. https://nccd.cdc.gov/drh_art/rdPage.aspx?rdReport=DRH_ ART. ClinicInfo\&ClinicId=9999\&ShowNational $=1$.

Clifford, Scott, and Jennifer Jerit. 2013. "How Words Do the Work of Politics: Moral Foundations Theory and the Debate Over Stem Cell Research." Journal of Politics 75(3):659-671.

Combs, Michael W., and Susan Welch. 1982. "Blacks, Whites, and Attitudes Toward Abortion." The Public Opinion Quarterly 46(4):510-520.

Connolly, Ceci. 2005. "Frist Breaks with Bush on Stem Cell Research." The Washington Post, July 30, 2005. Accessed March 30, 2017. http://www.washingtonpost.com/wpdyn/content/article/2005/07/29/AR2005072900158.html.

Converse, Philip E. 1964. "The Nature of Belief Systems in Mass Publics." Critical Review 18(1-3):1-74. DOI: 10.1080/08913810608443650.

Cook, Elizabeth Adell, Ted G. Jelen, and Clyde Wilcox. 1992. Between Two Absolutes: Public Opinion and the Politics of Abortion. Boulder, CO: Westview.

Culley, Lorraine, Nicky Hudson, and Floor van Rooj. 2013. Marginalized Reproduction: Ethnicity, Infertility and Reproductive Technologies. New York: Routledge.

Deckman, Melissa, and John McTague. 2015. "Did the 'War on Women' Work? Women, Men, and the Birth Control Mandate in the 2012 Presidential Election." American Politics Research 43(1):3-26.

Doan, Alesha E. 2014. "Morality Politics." In The Oxford Handbook of State and Local Government, ed. Donald P. Haider-Markel. New York: Oxford University Press, 757-777.

Dolgin, Janet L., Catherine Fisher, and Terri Shapiro. 2008. "Attitudes about Human Embryos, Embryonic Stem Cell Research, and Related Matters." Hofstra Law Review 37(2):319-381.

Donchin, Anne. 1986. "The Future of Mothering: Reproductive Technology and Feminist Theory." Hypatia 1(2):121-137. 
Donchin, Anne. 1996. "Feminist Critiques of New Fertility Technologies: Implications for Social Policy." Journal of Medicine and Philosophy 21(5):475-498.

Ellison, Christopher G., Samuel Echevarría, and Brad Smith. 2005. "Religion and Abortion Attitudes among U.S. Hispanics: Findings from the 1990 Latino National Political Survey." Social Science Quarterly 86(1):192-208.

Ferree, Myra Marx. 2002. Shaping Abortion Discourse: Democracy and the Public Sphere in Germany and the United States. New York: Cambridge University Press.

Finer, Lawrence B., and Stanley K. Henshaw. 2006. "Disparities in Rates of Unintended Pregnancy in the United States, 1994 and 2001." Perspectives on Sexual and Reproductive Health 38(2):90-96.

Fortin, Chelsea, and Susanne Abele. 2016. "Increased Length of Awareness of Assisted Reproductive Technologies Fosters Positive Attitudes and Acceptance among Women." International Journal of Fertility \& Sterility 9(4):452-464.

Franklin, Sarah. 1995. "Postmodern Procreation: A Cultural Account of Assisted Reproduction." In Conceiving the New World Order: The Global Politics of Reproduction, ed. Faye D. Ginsburg and Rayna Rapp. Berkeley: University of California Press, 323-345.

Gershon, Sarah Allen, Adrian D. Pantoja, and J. Benjamin Taylor. 2016. "God in the Barrio? The Determinants of Religiosity and Civic Engagement among Latinos in the United States." Politics and Religion 9(1):84-110.

Gibson, Troy, and Christopher Hare. 2012. "Do Latino Christians and Seculars Fit the Culture War Profile? Latino Religiosity and Political Behavior." Politics and Religion 5(1):53-82.

Haider-Markel, Donald P., and Kenneth J. Meier. 1996. "The Politics of Gay and Lesbian Rights: Expanding the Scope of the Conflict." The Journal of Politics 58(2):332-349.

Harwood, Karey. 2007. The Infertility Treadmill: Feminist Ethics, Personal Choice, and the Use of Reproductive Technologies. Chapel Hill, NC: University of North Carolina Press.

Haugeberg, Karissa. 2017. Women against Abortion: Inside the Largest Moral Reform Movement of the Twentieth Century. Chicago: University of Illinois Press.

Heidt-Forsythe, Erin. Forthcoming. Between Families and Frankenstein: The Politics of Egg Donation in the US. Oakland, CA: University of California Press.

Heidt-Forsythe, Erin Allison. 2013. Reconceiving the State. Unpublished doctoral dissertation. Rutgers, NJ: Rutgers University.

Hillygus, D. Sunshine and Todd G. Shields. 2014. The Persuadable Voter: Wedge Issues in Presidential Campaigns. Princeton, NJ: Princeton University Press.

Ho, Shirley S., Dominique Brossard, and Dietram A. Scheufele. 2008. "Effects of Value Predispositions, Mass Media Use, and Knowledge on Public Attitudes toward Embryonic Stem Cell Research.” International Journal of Public Opinion Research 20(2):171-192.

Holland, Suzanne, Karen Lebacqz, and Laurie Zoloth. 2001. The Human Embryonic Stem Cell Debate: Science, Ethics, and Public Policy. Cambridge, MA: MIT Press.

Huddy, Leonie, Erin Cassese, and Mary-Kate Lizotte. 2008. "Gender, Public Opinion, and Political Reasoning." In Political Women and American Democracy, ed. Christina Wolbrecht, Karen Beckwith and Lisa Baldez. New York: Cambridge University Press, $31-49$.

Hudson, Kathy L., Joan Scott, and Ruth Faden. "Values in Conflict": Public Attitudes on Embryonic Stem Cell Research. Phoebe R. Berman Bioethics Institute, Genetics and Public Policy Center. http://www.pewtrusts.org/ /media/legacy/uploadedfiles/www pewtrustsorg/reports/genetics_and_public_policy/gppcstemcellsurvey1005pdf.pdf.2005.

Hunter, James Davison, and Joseph E. Davis. 1995. "Cultural Politics at the Edge of Life." Journal of Policy History 7(1):103-127.

Inhorn, Marcia C., and Daphna Birenbaum-Carmeli. 2008. "Assisted Reproductive Technologies and Culture Change." Annual Review of Anthropology 37:177-196. 
Jasanoff, Sheila. 2011. Designs on Nature: Science and Democracy in Europe and the United States. Princeton, NJ: Princeton University Press.

Jelen, Ted G. 2014. "The Subjective Bases of Abortion Attitudes: A Cross National Comparison of Religious Traditions." Politics and Religion 7(3):550-567.

Jelen, Ted G., and Clyde Wilcox. 2003. "Causes and Consequences of Public Attitudes toward Abortion: A Review and Research Agenda." Political Research Quarterly 56(4):489-500.

Johnson, Judith A., and Edward C. Liu. 2012. Stem Cell Research: Science, Federal Research Funding, and Regulatory Oversight. Washington, DC: Congressional Research Service.

Kahn, Susan. 2000. Reproducing Jews: A Cultural Account of Assisted Conception in Israel. Durham, NC: Duke University Press.

Leal, David L. 2007. "Latino Public Opinion: Does it Exist?" In Latino Politics: Identity, Mobilization and Representation, ed. R. Espino, David L. Leal and Kenneth J. Meier. Charlottesville: University of Virginia Press, 27-42.

Liu, Hui, and Susanna Priest. 2009. "Understanding Public Support for Stem Cell Research: Media Communication, Interpersonal Communication and Trust in Key Actors." Public Understanding of Science 18(6):704-718.

Lizotte, Mary-Kate. 2015. "The Abortion Attitudes Paradox: Model Specification and Gender Differences." Journal of Women, Politics and Policy 36(1):22-42.

Lowi, Theodore J. 1998. "Foreword: New Dimensions in Policy and Politics." In Moral Controversies in American Politics: Cases in Social Regulatory Politics. 4th ed., ed. Raymond Tatalovich \& Byron Daynes, Armonk, NY: M.E. Sharpe, xiii-xxviii.

Luker, Kristin. 1984. Abortion and the Politics of Motherhood. Berkeley, CA: University of California Press.

McGee, Glenn, and Arthur L. Caplan. 1999. "The Ethics and Politics of Small Sacrifices in Stem Cell Research.” Kennedy Institute of Ethics Journal 9(2):151-158.

McTague, John, and Shanna Pearson-Merkowitz. 2013. "Voting from the Pew: The Effect of Senators' Religious Identities on Partisan Polarization in the U.S. Senate." Legislative Studies Quarterly 38(3):405-430.

McTague, John, and Shanna Pearson-Merkowitz. 2015 “"Thou Shalt Not Flip Flop: Senators' Religious Affiliations and Issue Position Consistency." Legislative Studies Quarterly 40(3):417-440.

Meier, Kenneth J. The Politics of Sin: Drugs, Alcohol and Public Policy. Armonk, NY: Sharpe, 1994.

Meilander, Gilbert. 2001. "The Point of A Ban: Or, How to Think about Stem Cell Research." The Hastings Center Report 31(1):9-16.

Mooney, Christopher Z. 2001. "The Public Clash of Private Values: The Politics of Morality Policy." In The Public Clash of Private Values, ed. Christopher Z. Mooney. New York: Chatham House Publishers, 3-20.

Mooney, Christopher Z., and Mei-Hsien Lee. 1995. "Legislative Morality in the American States: The Case of pre-Roe Abortion Regulation Reform." American Journal of Political Science 39(3):599-627.

Mottier, Véronique. 2013. "Reproductive Rights." In The Oxford Handbook of Gender and Politics, ed. Georgina Waylen, Karen Celis, Johanna Kantola and S. Laurel Weldon, New York: Oxford University Press. http://www.oxfordhandbooks.com/view/10. 1093/oxfordhb/9780199751457.001.0001/oxfordhb-9780199751457.

Nachtigall, Robert D., Gay Becker, Carrie Friese, Anneliese Butler, and Kirstin MacDougall. 2005. "Parents' Conceptualization of Their Frozen Embryos Complicates the Disposition Decision." Fertility and Sterility 84(2):431-434.

Nachtigall, Robert D., Kirstin MacDougall, Anne C. Davis, and Yewoubdar Beyene. 2012. “Expensive but Worth it: Older Parents' Attitudes and Opinions About the Costs and Insurance Coverage for In Vitro Fertilization.” Fertility and Sterility 97(1):82-87. 
NIH Stem Cell Information Home Page 2016. Stem Cell Information [World Wide Web site]. Bethesda, MD: National Institutes of Health, U.S. Department of Health and Human Services. Accessed May 11, 2017. https://stemcells.nih.gov/info/basics/1.htm.

Nisbet, Matthew C., Dominique Brossard, and Adrianne Kroepsch. 2003. "Framing Science: The Stem Cell Controversy in an Age of Press/Politics." The International Journal of Press/Politics 8(2):36-70.

Oldmixon, Elizabeth Anne, and Brian Robert Calfano. 2007. "The Religious Dynamics of Decision Making on Gay Rights Issues in the U.S. House of Representatives, 19932002." Journal for the Scientific Study of Religion 46(1): 55-70.

Pearson-Merkowitz, Shanna, and James G. Gimpel. 2009. "Religion and Political Socialization." In The Oxford Handbook of Religion and American Politics, ed. James L. Guth, Lyman A. Kellstedt and Corwin E. Smidt, New York: Oxford University Press. DOI:10.1093/oxfordhb/9780195326529.003.0006. http://www. oxfordhandbooks.com/view/10.1093/oxfordhb/9780195326529.001.0001/oxfordhb9780195326529-e-6.

Petchesky, Rosalind Pollack.: Abortion and Woman's Choice: The State, Sexuality, and Reproductive Freedom. Boston: Northeastern University Press, 1984.

Pew Research Center. 2013. Survey of Aging and Longevity. Washington, DC: Pew Research Center Religion and Public Life Project.

Reagan, Leslie J. 1997. When Abortion Was A Crime: Women, Medicine, and Law in the United States, 1867-1973. Oakland, CA: University of California Press.

Schroedel, Jean Reith. 2000. Is the Fetus A Person? A Comparison of Policies across the Fifty States. Ithaca, NY: Cornell University Press.

Scott, Jacqueline. 1989. "Conflicting Beliefs about Abortion: Legal Approval and Moral Doubts." Social Psychology Quarterly 52(4):319-326.

Scott, Jacqueline, and Howard Schuman. 1988. "Attitude Strength and Social Action in the Abortion Dispute." American Sociological Review 53:785-793.

Shih, Tsung-Jen, Dietram A. Scheufele, and Dominuque Brossard. 2013. "Disagreement and Value Predispositions: Understanding Public Opinion about Stem Cell Research." International Journal of Public Opinion Research 25(3):357-367.

Shreffler, Karina M., David R. Johnson, and Laurie K. Scheublec. 2010. "Ethical Problems with Infertility Treatments: Attitudes and Explanations." The Social Science Journal 47(4):731-746.

Sigillo, Alexandra E., Monica K. Miller, and Dana A. Weiser. 2012. "Attitudes toward Nontraditional Women Using IVF: The Importance of Political Affiliation and Religious Characteristics." Psychology of Religion and Spirituality 4(4):249-263.

Spar, Debora L. 2006. The Baby Business: How Money, Science, and Politics Drive the Commerce of Conception. Cambridge, MA: Harvard Business Review Press.

Stapleton, Patricia, and Daniel Skinner. 2015. "The Affordable Care Act and Assisted Reproductive Technology Use." Politics and Life Sciences 36(1):71-90.

Steensland, Brian, Jerry Z. Park, Mark D. Regnerus, Lynn D. Robinson, W. Bradford Wilcox, and Robert D. Woodberry. 2000. "The Measure of American Religion: toward Improving the State of the Art." Social Forces. 69(1):291-318.

Stetzer, Ed, and Ryan P. Burge. 2016. "Reltrad Coding Problems and A New Repository." Politics and Religion 9:187-190.

Strickler, Jennifer, and Nicholas Danigelis. 2002. "Changing Frameworks in Attitudes toward Abortion." Sociological Forum 17(2):187-201.

Sunderam, Saswati, Dmitry M. Kissin, Sara B. Crawford, Suzanne G. Folger, Denise J. Jamieson, Lee Warner, and Wanda D. Barfield. 2015. "Assisted Reproductive Technology Surveillance-United States, 2012.” MMWR Surveillance Summaries 64(6):1-32. 
Uhlaner, Carole Jean, and F. Chris Garcia. 2002. "Latino Public Opinion." In Understanding Public Opinion, ed. Barbara Norrander and Clyde Wilcox. Washington, DC: CQ Press, 77101.

Tatalovich, Raymond, Alexander Smith, and Michael P. Bobic. 1994. "Moral Conflict and the Policy Process." Policy Currents 4(40):3-6.

Tatalovich, Raymond, and Byron W. Daynes. 2011. Moral Controversies in American Politics. New York: M.E. Sharpe.

The American College of Obstetricians and Gynecologists. 2013. "Multifetal Pregnancy Reduction." Committee Opinion No. 553, February 2013. Accessed June 7, 2017. http://www.acog.org/-/media/Committee-Opinions/Committee-on-Ethics/co553.pdf?dmc= $1 \&$ ts $=20170608 \mathrm{~T} 1541375704$.

Thompson, Charis. 2013. Good Science: The Ethical Choreography of Stem Cell Research. Cambridge, MA: The MIT Press.

Tribe, Laurence H. 1992. Abortion: The Clash of Absolutes. New York: W.W. Norton \& Company.

Vestal, Christine. 2008. "Stem Cell Research at the Crossroads of Religion and Politics." Pew Research Center Religion and Public Life, July 17, 2008. Accessed March 29, 2017. http://www.pewforum.org/2008/07/17/stem-cell-research-at-the-crossroads-ofreligion-and-politics/.

Wald, Kenneth D., and Allison Calhoun-Brown. 2011. Religion and Politics in the United States. Lanham, MD: Rowman \& Littlefield.

Wilcox, Clyde. 1990. "Race Differences in Abortion Attitudes: Some Additional Evidence." Public Opinion Quarterly 54(2):248-255.

Wilcox, Clyde, and Barbara Norrander. 2002. "Of Moods and Morals: The Dynamics of Opinion on Abortion and Gay Rights." In Understanding Public Opinion. 3rd ed., ed. Barbara Norrander and Clyde Wilcox. Washington, DC: CQ Press, 121-148.

Wu, Alex K., Anobel Y. Odisho, Samuel L. Washington, III, Patricia P. Katz, and James F. Smith 2014. "Out-of-Pocket Fertility Patient Expense: Data from A Multicenter Prospective Infertility Cohort." The Journal of Urology 191(2):427-432.

\section{APPENDIX A. QUESTION-WORDING AND VARIABLE CODING}

\section{Dependent Variables}

"Do you personally believe that $\mathrm{xx}$ is morally acceptable, morally wrong, or is not a moral issue?" (a) Having an abortion; (b) medical research that uses embryonic stem cells (ESC research); (c) and using IVF (the order of these procedures was randomized during interviews).

- For Table 1: $0=$ all three procedures are morally wrong; $1=$ mixed views; $2=$ all three procedures are morally acceptable;

- For Table 2: $0=$ morally wrong; 1 = not a moral issue; $2=$ morally acceptable.

\section{Independent Variables}

Religiosity: How important is religion in your life? $1=$ very important; $2=$ somewhat important; 3 = not too important; $4=$ not at all important. 
Religious Denomination: Thinking now about your religion...

What is your present religion, if any? Are you Protestant, Roman Catholic, Mormon, Orthodox such as Greek or Russian Orthodox, Jewish, Muslim, Buddhist, Hindu, atheist, agnostic, something else, or nothing in particular?

- Responses recoded into dummy variables, where the reference group $(=0)$ is mainline Protestant (Baptist, Methodist, non-denominational, Lutheran, Presbyterian, Pentecostal, Episcopalian, Reformed, Church of Christ, Jehovah's Witness, etc.), excluding those who identify as Evangelical/born-again (see below);

- Dummy variables include: Roman Catholic (Catholic); Mormon (Church of Jesus Christ of Latter-day Saints/LDS); Jewish (Judaism); not religious (agnostic, atheist, not religious); other religion (a range of religious denominations, including Orthodox (Greek, Russian, or some other orthodox church), Muslim/Islam, Buddhist, Hindu, Something else, Unitarian Universalist, or "other" Christian).

Evangelical Protestant: Respondents who describe themselves as Christian were asked, Would you describe yourself as a "born-again" or Evangelical Christian, or not? 1 = yes, would; $2=$ no, would not. (Catholic respondents were excluded in order to capture Evangelical Protestants specifically)

Decade: "What is your age?" Responses are coded continuously by decade: $1=<20$ years old; $2=20-29 ; 3=30-39 ; 4=40-49 ; 5=50-59 ; 6=60-60 ; 7=70-79 ; 8=$ $80-89 ; 9=90-97$.

Female: 1 = female; $0=$ male.

Education: What is the highest level of school you have completed or the highest degree you have received? Coded continuously such that $8=$ less than high school; $10=$ high school incomplete (grades $9-11$ or grade 12 with NO diploma); $12=$ high school graduate with diploma or GED certificate; $14=$ some college/community college; $16=4$-year college or university degree/Bachelor's degree; 19 = graduate/professional schooling or postgraduate or professional degree.

Income: Last year, that is, in 2012, what was your total family income from all sources, before taxes? Just stop me when I get to the right category. Recoded as a series of dummy variables, as follows: $<\$ 10,000 ; \$ 10,000-30,000 ; \$ 30,000-50,000 ; \$ 50,000-75,000$; $\$ 75,000-100,000 ; \$ 100,000$ and above.

Race/ethnicity combines responses from two questions to create a series of dummy variables, where the reference group $(=0)$ is White non-Hispanic and other categories include Black non-Hispanic; Hispanic; other race.

Married: Are you currently married, living with a partner, divorced, separated, widowed, or have you never been married? Recoded so $1=$ married; $0=$ all other respondents.

Partisanship: In politics TODAY, do you consider yourself a Republican, Democrat, or independent? Recoded as a series of dummy variables, where reference group is all other respondents $(=0)$ :

- Democrat

- Republican

- Independent. 
Ideology: In general, would you describe your political views as.... 1 = very conservative; 2 = conservative; $3=$ moderate; $4=$ liberal; 5 = very liberal. Recoded as a series of dummy variables, where reference group $(=0)$ is all other respondents:

- Conservative: 1 = very conservative and conservative

- Liberal: 1 = very liberal and liberal

- Moderate: 1 = moderate.

\section{APPENDIX B. ADDITIONAL TABLES}

Table B1. Predicted probabilities: all three procedures morally wrong

\begin{tabular}{lccr}
\hline & Highest value & Lowest value & Change \\
\hline Religiosity & 0.08 & 0.01 & 0.07 \\
& $(0.06,0.09)$ & $(0.00,0.03)$ & \\
Evangelical Protestant & 0.13 & 0.04 & 0.09 \\
LDS & $(0.07,0.18)$ & $(0.03,0.05)$ & -0.07 \\
& 0.00 & 0.07 & 0.04 \\
Latino & $(0.00,0.00)$ & $(.05,0.08)$ & \\
& 0.10 & 0.06 & 0.03 \\
Conservative & $(0.06,0.14)$ & $(0.04,0.07)$ & -0.04 \\
Liberal & 0.08 & 0.05 & \\
& $(0.06,0.10)$ & $(0.03,0.06)$ & -0.05 \\
Income & 0.03 & 0.07 & \\
& $(0.01,0.04)$ & $(0.06,0.09)$ & 0.09 \\
& 0.04 & $(0.06,0.12)$ & \\
\hline
\end{tabular}

Table B2. Predicted probabilities: all three procedures morally acceptable

\begin{tabular}{lccr}
\hline & Highest value & Lowest value & Change \\
\hline Evangelical Protestant & 0.06 & 0.11 & -0.05 \\
& $(0.03,0.09)$ & $(0.09,0.13)$ & -0.10 \\
LDS & 0.00 & 0.10 & -0.05 \\
& $(0.00,0.00)$ & $(0.08,0.11)$ & 0.05 \\
Conservative & 0.06 & 0.11 & 0.09 \\
Democrat & $(0.03,0.09)$ & 0.08 & $0.14)$ \\
Decade & 0.13 & $(0.06,0.10)$ & \\
& $(0.10,0.16)$ & 0.07 & \\
& 0.16 & $(0.05,0.09)$ &
\end{tabular}


Table B3. Predicted probabilities: abortion morally wrong

\begin{tabular}{lccr}
\hline & Highest & Lowest & Change \\
\hline Religiosity & 0.66 & 0.36 & 0.30 \\
& $(0.62,0.69)$ & $(0.27,0.45)$ & \\
Evangelical Protestant & 0.67 & 0.50 & 0.17 \\
& $(0.62,0.72)$ & $(0.47,0.53)$ & \\
Jewish & 0.39 & 0.55 & -0.16 \\
& $(0.24,0.55)$ & $(0.53,0.57)$ & \\
Married & 0.59 & 0.51 & 0.08 \\
& $(0.56,0.62)$ & $(0.48,0.54)$ & \\
Conservative & 0.63 & 0.50 & 0.13 \\
& $(0.59,0.67)$ & $(0.46,0.52)$ & \\
Liberal & 0.49 & 0.57 & -0.08 \\
& $(0.45,0.54)$ & $(0.54,0.59)$ & 0.10 \\
Democrat & 0.48 & 0.58 & \\
& $(0.44,0.52)$ & $(0.56,0.61)$ & -0.18 \\
Income & 0.46 & 0.64 & \\
& $(0.42,0.52)$ & $(0.60,0.67)$ & \\
\end{tabular}

Table B4. Predicted probabilities: abortion morally acceptable

\begin{tabular}{lccr}
\hline & Highest & Lowest & Change \\
\hline Female & 0.16 & 0.21 & -0.05 \\
& $(0.14,0.19)$ & $(0.18,0.23)$ & 0.09 \\
Democrat & 0.24 & 0.15 & 0.08 \\
Income & $(0.20,0.28)$ & $(0.13,0.18)$ & \\
& 0.24 & 0.16 & \\
& $(0.20,0.29)$ & $(0.13,0.19)$ & \\
\hline
\end{tabular}


Table B5. Predicted probabilities: ESC research morally wrong

\begin{tabular}{lccr}
\hline & Highest & Lowest & Change \\
\hline Religiosity & 0.29 & 0.13 & 0.16 \\
Evangelical Protestant & $(0.26,0.32)$ & $(0.05,0.21)$ & 0.14 \\
Conservative & 0.34 & 0.20 & \\
& $(0.28,0.40)$ & $(0.17,0.23)$ & 0.08 \\
Republican & 0.29 & 0.21 & 0.06 \\
Democrat & $(0.25,0.32)$ & $(0.18,0.23)$ & 0.10 \\
Income & 0.29 & $(0.20,0.25)$ & \\
& $(0.24,0.33)$ & 0.58 & -0.10 \\
& 0.48 & $(0.56,0.61)$ & \\
\hline
\end{tabular}

Table B6. Predicted probabilities: ESC research morally acceptable

\begin{tabular}{lccr}
\hline & Highest & Lowest & Change \\
\hline African American & 0.31 & 0.37 & -0.06 \\
& $(0.25,0.37)$ & $(0.25,0.40)$ & 0.09 \\
Democrat & 0.43 & 0.34 & 0.15 \\
\multirow{2}{*}{ Decade } & $(0.38,0.47)$ & $0.31,0.37)$ & \\
& 0.46 & $(0.26,0.35)$ & \\
\hline
\end{tabular}

Table B7. Predicted probabilities: IVF morally wrong

\begin{tabular}{lccr}
\hline & Highest & Lowest & Change \\
\hline Religiosity & 0.15 & 0.05 & 0.10 \\
Female & $(0.12,0.17)$ & $(0.01,0.08)$ & -0.04 \\
& 0.10 & 0.14 & 0.09 \\
Other race & $(0.08,0.12)$ & $(0.12,0.16)$ & 0.05 \\
Conservative & 0.20 & $(0.10,0.13)$ & \\
& $(0.12,0.27)$ & 0.10 & -0.04 \\
Liberal & 0.15 & $(0.08,0.12)$ & \\
& $(0.12,0.18)$ & 0.13 & -0.09 \\
Income & 0.09 & $0.11,0.15)$ & \\
& $(0.06,0.12)$ & $(0.14,0.21)$ & \\
& 0.08 & $(0.05,0.11)$ &
\end{tabular}


Table B8. Predicted probabilities: IVF morally acceptable

\begin{tabular}{lccr}
\hline & Highest & Lowest & Change \\
\hline LDS & 0.61 & 0.36 & 0.25 \\
& $(0.43,0.79)$ & $(0.34,0.39)$ & -0.10 \\
African American & 0.28 & 0.38 & -0.04 \\
\multirow{2}{*}{ Liberal } & $(0.22,0.33)$ & $(0.35,0.41)$ & 0.38 \\
\multirow{2}{*}{ Democrat } & 0.34 & $(0.35,0.41)$ & 0.08 \\
& $(0.29,0.38)$ & 0.34 & \\
\hline
\end{tabular}

Table B9. Logistic regression analysis, are embryonic policies morally unacceptable or morally acceptable/not a moral issue?

\begin{tabular}{|c|c|c|c|}
\hline & $\begin{array}{c}\text { (1) } \\
\text { Abortion }\end{array}$ & $\begin{array}{c}(2) \\
\text { ESC research }\end{array}$ & $\begin{array}{l}\text { (3) } \\
\text { IVF }\end{array}$ \\
\hline \multicolumn{4}{|l|}{ Religiosity } \\
\hline Very important & $\begin{array}{l}1.53 * * * \\
(0.27)\end{array}$ & $\begin{array}{l}1.08^{* *} \\
(0.41)\end{array}$ & $\begin{array}{l}1.29 * * \\
(0.42)\end{array}$ \\
\hline Somewhat important & $\begin{array}{l}0.54^{*} \\
(0.27)\end{array}$ & $\begin{array}{c}0.53 \\
(0.41)\end{array}$ & $\begin{array}{c}0.76^{\wedge} \\
(0.43)\end{array}$ \\
\hline Not too important & $\begin{array}{c}-0.03 \\
(0.32)\end{array}$ & $\begin{array}{c}-0.21 \\
(0.44)\end{array}$ & $\begin{array}{c}0.51 \\
(0.50)\end{array}$ \\
\hline \multicolumn{4}{|l|}{ Denomination } \\
\hline Evangelical Protestant & $\begin{array}{l}0.95 * * * \\
(0.20)\end{array}$ & $\begin{array}{l}0.85 * * * \\
(0.22)\end{array}$ & $\begin{array}{c}0.32 \\
(0.29)\end{array}$ \\
\hline Catholic & $\begin{array}{l}0.47^{*} \\
(0.19)\end{array}$ & $\begin{array}{r}0.40^{\wedge} \\
(0.23)\end{array}$ & $\begin{array}{c}0.09 \\
(0.30)\end{array}$ \\
\hline LDS & $\begin{array}{c}0.59 \\
(0.45)\end{array}$ & $\begin{array}{c}-0.03 \\
(0.47)\end{array}$ & $\begin{array}{c}-1.97 * * \\
(0.73)\end{array}$ \\
\hline Jewish & $\begin{array}{c}-0.88^{\wedge} \\
(0.47)\end{array}$ & $\begin{array}{c}-0.32 \\
(0.59)\end{array}$ & $\begin{array}{c}0.53 \\
(0.65)\end{array}$ \\
\hline Not religious & $\begin{array}{c}-0.24 \\
(0.24)\end{array}$ & $\begin{array}{c}0.03 \\
(0.33)\end{array}$ & $\begin{array}{c}0.26 \\
(0.36)\end{array}$ \\
\hline Other religion & $\begin{array}{c}0.08 \\
(0.26)\end{array}$ & $\begin{array}{c}0.03 \\
(0.33)\end{array}$ & $\begin{array}{c}0.02 \\
(0.40)\end{array}$ \\
\hline \multicolumn{4}{|l|}{ Demographics } \\
\hline Female & $\begin{array}{c}-0.08 \\
(0.13)\end{array}$ & $\begin{array}{l}-0.12 \\
(0.13)\end{array}$ & $\begin{array}{c}-0.42 * * \\
(0.16)\end{array}$ \\
\hline Married & $\begin{array}{l}0.50^{* * * *} \\
(0.14)\end{array}$ & $\begin{array}{c}0.08 \\
(0.15)\end{array}$ & $\begin{array}{c}0.14 \\
(0.18)\end{array}$ \\
\hline African American & $\begin{array}{c}-0.08 \\
(0.20)\end{array}$ & $\begin{array}{c}-0.20 \\
(0.20)\end{array}$ & $\begin{array}{c}0.11 \\
(0.25)\end{array}$ \\
\hline
\end{tabular}


Table B9. Continued

\begin{tabular}{|c|c|c|c|}
\hline & $\begin{array}{c}\text { (1) } \\
\text { Abortion }\end{array}$ & $\begin{array}{c}(2) \\
\text { ESC research }\end{array}$ & $\begin{array}{l}\text { (3) } \\
\text { IVF }\end{array}$ \\
\hline Latino & $\begin{array}{c}0.19 \\
(0.17)\end{array}$ & $\begin{array}{c}0.17 \\
(0.19)\end{array}$ & $\begin{array}{l}0.68 * * * \\
(0.21)\end{array}$ \\
\hline Other race & $\begin{array}{c}-0.18 \\
(0.24)\end{array}$ & $\begin{array}{c}0.46^{\wedge} \\
(0.26)\end{array}$ & $\begin{array}{c}0.72 * \\
(0.30)\end{array}$ \\
\hline Decade & $\begin{array}{c}-0.08^{*} \\
(0.04)\end{array}$ & $\begin{array}{c}-0.09^{*} \\
(0.04)\end{array}$ & $\begin{array}{c}0.07 \\
(0.05)\end{array}$ \\
\hline Education & $\begin{array}{c}-0.01 \\
(0.02)\end{array}$ & $\begin{array}{c}-0.02 \\
(0.02)\end{array}$ & $\begin{array}{c}-0.05 \\
(0.03)\end{array}$ \\
\hline \multicolumn{4}{|l|}{ Ideology/partisanship } \\
\hline Conservative & $\begin{array}{l}0.77 * * * \\
(0.15)\end{array}$ & $\begin{array}{l}0.50^{* *} \\
(0.15)\end{array}$ & $\begin{array}{l}0.50 * * \\
(0.19)\end{array}$ \\
\hline Liberal & $\begin{array}{c}-0.43 * * \\
(0.16)\end{array}$ & $\begin{array}{c}-0.38^{*} \\
(0.19)\end{array}$ & $\begin{array}{c}-0.45^{*} \\
(0.23)\end{array}$ \\
\hline Democrat & $\begin{array}{c}-0.57 * * * \\
(0.15)\end{array}$ & $\begin{array}{c}-0.41 * \\
(0.17)\end{array}$ & $\begin{array}{c}-0.01 \\
(0.19)\end{array}$ \\
\hline Republican & $\begin{array}{c}0.30^{\wedge} \\
(0.17)\end{array}$ & $\begin{array}{c}0.36^{*} \\
(0.16)\end{array}$ & $\begin{array}{c}-0.26 \\
(0.22)\end{array}$ \\
\hline \multicolumn{4}{|l|}{ Income } \\
\hline$\$ 30,000-50,000$ & $\begin{array}{c}-0.68 * * * \\
(0.18)\end{array}$ & $\begin{array}{c}-0.12 \\
(0.18)\end{array}$ & $\begin{array}{c}-0.67 * * \\
(0.21)\end{array}$ \\
\hline$\$ 50,000-75,000$ & $\begin{array}{c}-0.76^{* * *} \\
(0.21)\end{array}$ & $\begin{array}{c}-0.46^{*} \\
(0.22)\end{array}$ & $\begin{array}{c}-0.95 * * * \\
(0.28)\end{array}$ \\
\hline$\$ 75,000-100,000$ & $\begin{array}{c}-0.87 * * * \\
(0.21)\end{array}$ & $\begin{array}{c}-0.09 \\
(0.22)\end{array}$ & $\begin{array}{c}-0.58^{*} \\
(0.28)\end{array}$ \\
\hline$>\$ 100,000$ & $\begin{array}{l}-1.01 * * * \\
(0.20)\end{array}$ & $\begin{array}{c}-0.67 * * * \\
(0.21)\end{array}$ & $\begin{array}{c}-0.95^{* * * *} \\
(0.29)\end{array}$ \\
\hline Constant & $\begin{array}{c}-0.31 \\
(0.50)\end{array}$ & $\begin{array}{c}-1.67 * * \\
(0.62)\end{array}$ & $\begin{array}{c}-2.42 * * * \\
(0.74)\end{array}$ \\
\hline Observations & 2,827 & 2,908 & 2,954 \\
\hline
\end{tabular}

Coefficients are odds ratios with robust standard errors in parentheses. Significance levels: ${ }^{\wedge} p<0.10$, ${ }^{*} p \leq 0.05, * * p<0.01, * * * p<0.001$. 
Table B10. Multinomial regression, are abortion, ESC research, and IVF morally wrong or morally acceptable (compared with not a moral issue), with interactions

\begin{tabular}{|c|c|c|c|c|c|c|}
\hline & \multicolumn{2}{|c|}{ Abortion } & \multicolumn{2}{|c|}{ ESC research } & \multicolumn{2}{|c|}{ IVF } \\
\hline & $\begin{array}{c}\text { (1) } \\
\text { Morally } \\
\text { wrong }\end{array}$ & $\begin{array}{c}(2) \\
\text { Morally } \\
\text { acceptable }\end{array}$ & $\begin{array}{c}\text { (3) } \\
\text { Morally } \\
\text { wrong }\end{array}$ & $\begin{array}{c}(4) \\
\text { Morally } \\
\text { acceptable }\end{array}$ & $\begin{array}{c}(5) \\
\text { Morally } \\
\text { wrong }\end{array}$ & $\begin{array}{c}(6) \\
\text { Morally } \\
\text { acceptable }\end{array}$ \\
\hline \multicolumn{7}{|l|}{ Religiosity } \\
\hline Very important & $\begin{array}{l}1.46^{* * * *} \\
(0.29)\end{array}$ & $\begin{array}{c}-0.15 \\
(0.27)\end{array}$ & $\begin{array}{l}1.23^{* *} \\
(0.42)\end{array}$ & $\begin{array}{c}0.32 \\
(0.22)\end{array}$ & $\begin{array}{l}1.39 * * * \\
(0.43)\end{array}$ & $\begin{array}{c}0.24 \\
(0.22)\end{array}$ \\
\hline Somewhat important & $\begin{array}{c}0.41 \\
(0.29)\end{array}$ & $\begin{array}{c}-0.31 \\
(0.25)\end{array}$ & $\begin{array}{c}0.62 \\
(0.42)\end{array}$ & $\begin{array}{c}0.22 \\
(0.22)\end{array}$ & $\begin{array}{c}0.86^{*} \\
(0.44)\end{array}$ & $\begin{array}{c}0.25 \\
(0.22)\end{array}$ \\
\hline Not too important & $\begin{array}{c}-0.075 \\
(0.34)\end{array}$ & $\begin{array}{c}-0.08 \\
(0.27)\end{array}$ & $\begin{array}{c}-0.16 \\
(0.46)\end{array}$ & $\begin{array}{c}0.12 \\
(0.24)\end{array}$ & $\begin{array}{c}0.67 \\
(0.50)\end{array}$ & $\begin{array}{c}0.36 \\
(0.24)\end{array}$ \\
\hline \multicolumn{7}{|l|}{ Denomination } \\
\hline Evangelical Protestant & $\begin{array}{l}0.89 * * * \\
(0.23)\end{array}$ & $\begin{array}{c}-0.17 \\
(0.28)\end{array}$ & $\begin{array}{l}0.80 * * * \\
(0.24)\end{array}$ & $\begin{array}{c}-0.12 \\
(0.20)\end{array}$ & $\begin{array}{c}0.23 \\
(0.30)\end{array}$ & $\begin{array}{c}-0.25 \\
(0.18)\end{array}$ \\
\hline Catholic & $\begin{array}{c}0.35 \\
(0.21)\end{array}$ & $\begin{array}{c}-0.31 \\
(0.27)\end{array}$ & $\begin{array}{c}0.33 \\
(0.25)\end{array}$ & $\begin{array}{c}-0.14 \\
(0.20)\end{array}$ & $\begin{array}{c}-0.03 \\
(0.31)\end{array}$ & $\begin{array}{c}-0.28 \\
(0.18)\end{array}$ \\
\hline LDS & $\begin{array}{c}0.41 \\
(0.55)\end{array}$ & $\begin{array}{c}-0.52 \\
(0.77)\end{array}$ & $\begin{array}{c}0.12 \\
(0.55)\end{array}$ & $\begin{array}{c}0.28 \\
(0.52)\end{array}$ & $\begin{array}{c}-1.44 \\
(0.76)\end{array}$ & $\begin{array}{c}0.91 * \\
(0.41)\end{array}$ \\
\hline Jewish & $\begin{array}{c}-1.03^{*} \\
(0.50)\end{array}$ & $\begin{array}{c}-0.37 \\
(0.45)\end{array}$ & $\begin{array}{c}-0.45 \\
(0.62)\end{array}$ & $\begin{array}{c}-0.26 \\
(0.38)\end{array}$ & $\begin{array}{c}0.29 \\
(0.67)\end{array}$ & $\begin{array}{c}-0.55 \\
(0.36)\end{array}$ \\
\hline Not religious & $\begin{array}{c}-0.23 \\
(0.26)\end{array}$ & $\begin{array}{c}0.04 \\
(0.26)\end{array}$ & $\begin{array}{c}0.15 \\
(0.34)\end{array}$ & $\begin{array}{c}0.28 \\
(0.21)\end{array}$ & $\begin{array}{c}0.29 \\
(0.37)\end{array}$ & $\begin{array}{c}0.07 \\
(0.21)\end{array}$ \\
\hline Other religion & $\begin{array}{c}-0.01 \\
(0.29)\end{array}$ & $\begin{array}{c}-0.23 \\
(0.32)\end{array}$ & $\begin{array}{c}0.02 \\
(0.35)\end{array}$ & $\begin{array}{c}-0.03 \\
(0.25)\end{array}$ & $\begin{array}{c}-0.06 \\
(0.41)\end{array}$ & $\begin{array}{c}-0.21 \\
(0.23)\end{array}$ \\
\hline \multicolumn{7}{|l|}{ Demographics } \\
\hline Female & $\begin{array}{c}-0.24 \\
(0.47)\end{array}$ & $\begin{array}{c}-0.50 \\
(0.58)\end{array}$ & $\begin{array}{c}0.17 \\
(0.47)\end{array}$ & $\begin{array}{c}-0.84 * \\
(0.42)\end{array}$ & $\begin{array}{c}-0.63 \\
(0.53)\end{array}$ & $\begin{array}{c}-0.23 \\
(0.41)\end{array}$ \\
\hline
\end{tabular}




\begin{tabular}{|c|c|c|c|c|c|c|}
\hline & \multicolumn{2}{|c|}{ Abortion } & \multicolumn{2}{|c|}{ ESC research } & \multicolumn{2}{|c|}{ IVF } \\
\hline & $\begin{array}{c}\text { (1) } \\
\text { Morally } \\
\text { wrong }\end{array}$ & $\begin{array}{c}(2) \\
\text { Morally } \\
\text { acceptable }\end{array}$ & $\begin{array}{c}\text { (3) } \\
\text { Morally } \\
\text { wrong }\end{array}$ & $\begin{array}{c}(4) \\
\text { Morally } \\
\text { acceptable }\end{array}$ & $\begin{array}{c}\text { (5) } \\
\text { Morally } \\
\text { wrong }\end{array}$ & $\begin{array}{c}(6) \\
\text { Morally } \\
\text { acceptable }\end{array}$ \\
\hline Married & $\begin{array}{l}0.51^{* * *} \\
(0.15)\end{array}$ & $\begin{array}{c}0.04 \\
(0.16)\end{array}$ & $\begin{array}{c}0.12 \\
(0.16)\end{array}$ & $\begin{array}{c}0.12 \\
(0.13)\end{array}$ & $\begin{array}{c}0.19 \\
(0.19)\end{array}$ & $\begin{array}{c}0.14 \\
(0.12)\end{array}$ \\
\hline African American & $\begin{array}{c}-0.14 \\
(0.30)\end{array}$ & $\begin{array}{c}-0.18 \\
(0.32)\end{array}$ & $\begin{array}{c}-0.36 \\
(0.29)\end{array}$ & $\begin{array}{c}-0.19 \\
(0.24)\end{array}$ & $\begin{array}{c}0.12 \\
(0.33)\end{array}$ & $\begin{array}{c}-0.56^{*} \\
(0.24)\end{array}$ \\
\hline African American female & $\begin{array}{c}-0.10 \\
(0.37)\end{array}$ & $\begin{array}{c}-0.30 \\
(0.42)\end{array}$ & $\begin{array}{c}0.03 \\
(0.37)\end{array}$ & $\begin{array}{c}0.41 \\
(0.31)\end{array}$ & $\begin{array}{c}0.41 \\
(0.43)\end{array}$ & $\begin{array}{c}-0.09 \\
(0.30)\end{array}$ \\
\hline Latino & $\begin{array}{c}0.17 \\
(0.26)\end{array}$ & $\begin{array}{c}-0.01 \\
(0.31)\end{array}$ & $\begin{array}{c}-0.16 \\
(0.28)\end{array}$ & $\begin{array}{c}-0.00 \\
(0.23)\end{array}$ & $\begin{array}{l}0.60 * \\
(0.30)\end{array}$ & $\begin{array}{c}0.21 \\
(0.23)\end{array}$ \\
\hline Latino female & $\begin{array}{c}0.09 \\
(0.33)\end{array}$ & $\begin{array}{c}0.34 \\
(0.44)\end{array}$ & $\begin{array}{c}-0.46 \\
(0.34)\end{array}$ & $\begin{array}{c}0.39 \\
(0.31)\end{array}$ & $\begin{array}{c}-0.11 \\
(0.38)\end{array}$ & $\begin{array}{c}0.56 \\
(0.30)\end{array}$ \\
\hline Other race & $\begin{array}{c}-0.31 \\
(0.27)\end{array}$ & $\begin{array}{c}-0.32 \\
(0.30)\end{array}$ & $\begin{array}{c}0.30 \\
(0.27)\end{array}$ & $\begin{array}{c}-0.33 \\
(0.25)\end{array}$ & $\begin{array}{c}0.66^{*} \\
(0.31)\end{array}$ & $\begin{array}{c}-0.14 \\
(0.23)\end{array}$ \\
\hline Decade & $\begin{array}{c}-0.08 \\
(0.04)\end{array}$ & $\begin{array}{c}0.02 \\
(0.05)\end{array}$ & $\begin{array}{c}-0.06 \\
(0.04)\end{array}$ & $\begin{array}{c}0.07 * \\
(0.04)\end{array}$ & $\begin{array}{c}0.09 \\
(0.05)\end{array}$ & $\begin{array}{c}0.04 \\
(0.03)\end{array}$ \\
\hline Education & $\begin{array}{c}-0.01 \\
(0.03)\end{array}$ & $\begin{array}{c}0.03 \\
(0.03)\end{array}$ & $\begin{array}{c}-0.01 \\
(0.03)\end{array}$ & $\begin{array}{c}0.03 \\
(0.02)\end{array}$ & $\begin{array}{c}-0.04 \\
(0.036)\end{array}$ & $\begin{array}{c}0.02 \\
(0.02)\end{array}$ \\
\hline Ideology & & & & & & \\
\hline Conservative & $\begin{array}{l}0.84 * * * \\
(0.17)\end{array}$ & $\begin{array}{c}0.21 \\
(0.24)\end{array}$ & $\begin{array}{l}0.47 * * \\
(0.17)\end{array}$ & $\begin{array}{c}-0.03 \\
(0.15)\end{array}$ & $\begin{array}{c}0.50 * \\
(0.20)\end{array}$ & $\begin{array}{c}0.04 \\
(0.13)\end{array}$ \\
\hline Liberal & $\begin{array}{c}-0.36^{*} \\
(0.17)\end{array}$ & $\begin{array}{c}0.18 \\
(0.18)\end{array}$ & $\begin{array}{c}-0.36 \\
(0.21)\end{array}$ & $\begin{array}{c}0.03 \\
(0.14)\end{array}$ & $\begin{array}{c}-0.56^{*} \\
(0.24)\end{array}$ & $\begin{array}{c}-0.28^{*} \\
(0.14)\end{array}$ \\
\hline Democrat & $\begin{array}{c}-0.40^{*} \\
(0.16)\end{array}$ & $\begin{array}{l}0.44^{*} \\
(0.18)\end{array}$ & $\begin{array}{c}-0.27 \\
(0.18)\end{array}$ & $\begin{array}{l}0.31^{*} \\
(0.14)\end{array}$ & $\begin{array}{c}0.14 \\
(0.20)\end{array}$ & $\begin{array}{l}0.38^{* * *} \\
(0.13)\end{array}$ \\
\hline
\end{tabular}


Table B10. Continued

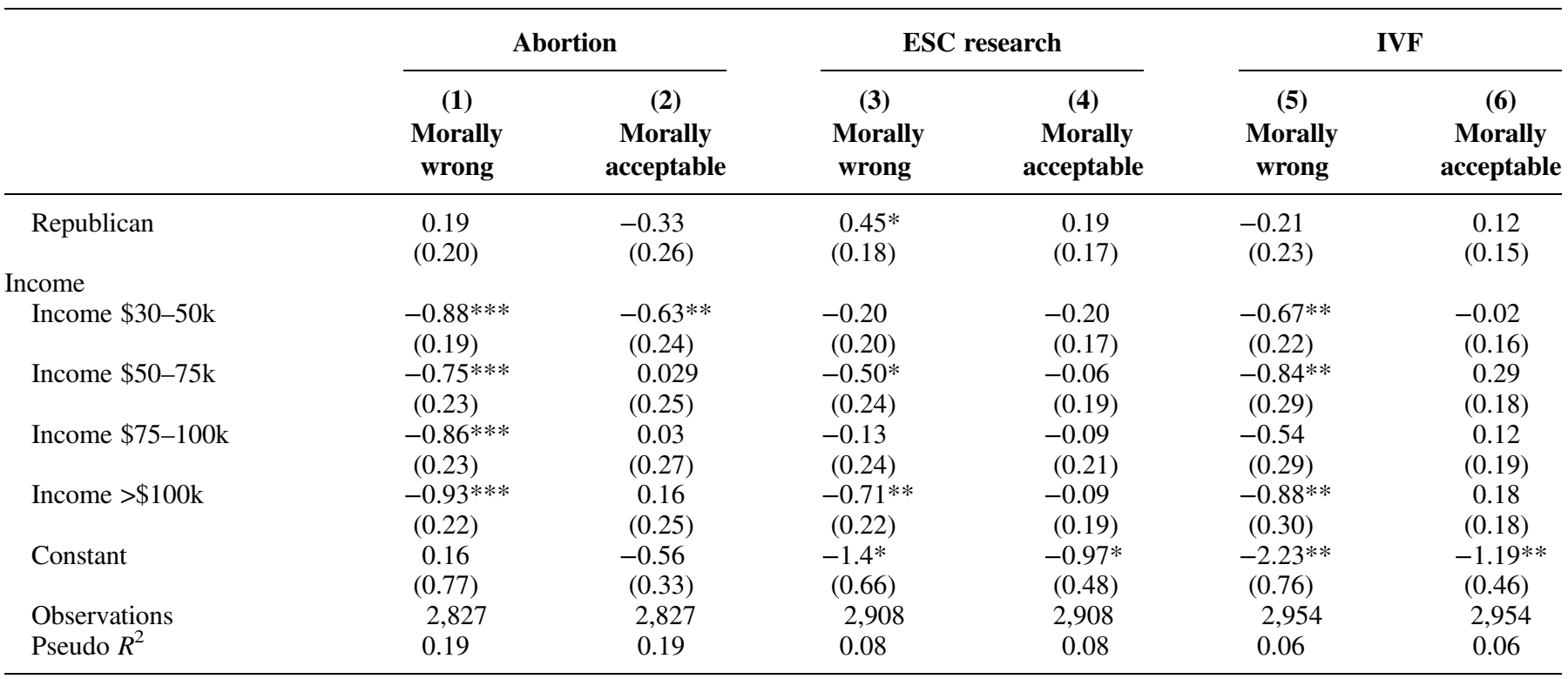

Robust standard errors are in parentheses. Significance levels: $* p \leq 0.05, * * p<0.01, * * * p<0.001$ 